\title{
An isotopic generation: four decades of stable isotope analysis in African archaeology
}

\author{
Emma Loftus ${ }^{1}$, Patrick Roberts ${ }^{1}$, Julia A. Lee-Thorp ${ }^{1}$ \\ ${ }^{1}$ School of Archaeology, Research Laboratory for Archaeology and the History of Art, \\ University of Oxford, Dyson Perrins Building, South Parks Road, Oxford OX1 3QY, United \\ Kingdom
}

The application of stable isotope analysis in African archaeology has a long and distinguished pedigree. Many new developments were inspired by questions in the archaeology of the continent, helped considerably by the availability of African landscapes as natural laboratories for providing the essential underpinning of isotope ecology systematics. Stable isotopes are now regularly built into multi-disciplinary archaeological projects spanning the very long temporal and geographical span of human history on the African continent. On the fiftieth anniversary of Azania: Archaeological Research in Africa we evaluate these endeavours - the achievements, problems, constraints and potential of stable isotopic research in African archaeology. We begin with a discussion of the continent's role in developing understandings of stable carbon, nitrogen, oxygen and strontium isotope systematics, as used to interpret change in the archaeological record. We discuss the application of these principles within several areas of archaeological research, drawing on case studies in the Late Pleistocene/Holocene human hunter-gatherers, early food producers, complex societies of the African Iron Age and the individual life histories of the African slave trade. There is clearly much potential for further application in African archaeology.

\section{Introduction}

It is nearly forty years since the isotopic results for an African burial inspired a fresh avenue of investigation in palaeodietary research. In 1970, Nikolaas van der Merwe, a recent graduate of Yale University, was excavating sites around Phalaborwa, South Africa, when he discovered an unusual burial, a man of apparently Khoisan descent buried within an otherwise distinctively Iron Age settlement (van der Merwe 1982). Stable carbon isotope measurements of his bone collagen undertaken during the course of radiocarbon dating appeared to show that this Khoisan man had eaten a diet similar to that of Bantu agriculturalists. These observations raised numerous questions about hunter-gatherer/farmer interactions in the region, but importantly also hinted at the power of stable isotope analyses to address broad archaeological questions. Van der Merwe, together with radiocarbon and isotope specialist John Vogel, went on to apply the newly acquired understandings of carbon isotope pathways in photosynthesis (Smith and Epstein 1971) and ecological foodchains (DeNiro and Epstein 1978: 1981) to investigating the spread of maize agriculture among North American foragers (Vogel and van der Merwe 1977; van der Merwe and Vogel 1978). The importance of stable isotope approaches for archaeologists was soon firmly established.

Van der Merwe and his students (and their students) have subsequently explored a whole range of applications of relevance in archaeology including palaeodietary and environmental research. These included the contribution of marine and terrestrial dietary inputs among hunter-gatherers (Sealy and van der Merwe 1985, 1986), coastal hunter-gatherer mobility (Sealy 2006), Iron Age agriculturalist diets (Lee-Thorp et al. 1993), the origins and diets of slaves (Sealy et al. 1993, 1995; Cox and Sealy, 1997), the use of archaeological materials as palaeoenvironmental proxies (Von Schirnding et al. 1982; Cohen et al. 1992; February et al. 1992), and the extension of stable isotope dietary studies into deep time (Lee-Thorp and van 
der Merwe 1987; Lee-Thorp et al. 1989) that opened a whole new arena of investigation into hominin diets (Lee-Thorp et al. 2000, 2010). The methods of stable isotope analysis are now used routinely to examine prehistoric human climates, environments, ecologies and diets on the broadest of scales. African landscapes and archaeology have, in no small part, been central to the growth and maturation of archaeological stable isotope applications, providing the experimental grounding for sensible and nuanced archaeological interpretation.

Here, on the fiftieth anniversary of Azania: Archaeological Research in Africa we evaluate stable isotope application in African archaeology. We begin by analysing current understandings of the main factors driving the variation of stable carbon, nitrogen, oxygen and strontium isotopes in terrestrial ecosystems, with particular focus on modern studies in Africa that have increased our understanding of these 'stable isotope ecologies'. We then use these principles to explore, in temporal order, the application of stable light isotope analysis to hunter-gatherer lifeways and landscape use, the origins and development of food production in Africa, the major social transitions of the Iron Age in many regions of Africa and the individual life histories of the African slave trade. Given the abundance of work on African hominin diet, ecologies and mobility we do not discuss this here, but rather point readers towards several comprehensive reviews (e.g. Lee-Thorp et al. 2010; Sponheimer et al. 2009, 2013). While the themes we address do not exhaustively cover the entirety of stable isotope research and potential in Africa, we hope to demonstrate the variety and types of question, as well as time periods and ecological settings, penetrable to stable light isotope methodology, while also suggesting some directions for future research and clarification.

\section{Stable isotope ecology in an African context}

Twenty-five years ago, Sillen et al. (1989) identified the major hurdles for future applications of stable isotope research in archaeology. Subtitled 'No more easy answers', their article described the need for detailed isotope ecology studies to tackle nuanced archaeological questions. Despite the notable successes and promising developments for archaeological applications of geochemical techniques seen in the previous decade and a half, some basic uncertainties persisted, primarily related to natural variations in stable isotope distributions among plants and animals under different environmental conditions. These uncertainties are not easily addressed, since they require carefully planned research programmes to map natural ecological isotope variability. Fortunately, African landscapes provide researchers with the natural laboratories and varied experimental conditions to parse the environmental controls on natural isotope variation.

\section{Stable carbon isotopes}

The primary driver of $\delta^{13} \mathrm{C}$ variation in African ecosystems is the marked isotopic distinction between the two dominant photosynthetic pathways, respectively known as $\mathrm{C}_{3}$ and $\mathrm{C}_{4}$, that differ in their net discrimination against ${ }^{13} \mathrm{C}$ during fixation of $\mathrm{CO}_{2}$ (Craig 1953; Smith and Epstein 1971; Farquhar et al. 1989). Plants employing the $\mathrm{C}_{3}$ pathway, including trees, most woody shrubs, herbs and temperate or shade-loving grasses, have low or negative $\delta^{13} \mathrm{C}$ values $^{1}$ (about -24 to $-36 \%$; global mean $=-26.5 \%$ ) as a result of strong discrimination against ${ }^{13} \mathrm{C}$. Plants using the $\mathrm{C}_{4}$ photosynthetic pathway ( -9 to $-17 \%$; global mean $=-12 \%$ ), typically tropical grasses, make more efficient use of available $\mathrm{CO}_{2}$ and do not discriminate as strongly against the heavy ${ }^{13} \mathrm{C}$ isotope. $\mathrm{C}_{3}$ and $\mathrm{C}_{4} \delta^{13} \mathrm{C}$ values are therefore distinct and non-overlapping (Figure 2). This picture is made more complex by Crassulacean Acid 
Metabolism (CAM) plants that can have $\delta^{13} \mathrm{C}$ values that overlap with those of $\mathrm{C}_{3}$ or $\mathrm{C}_{4}$ plants, though these plants tend to be limited to more arid regions (O'Leary 1981).

These photosynthetic pathways are adaptive responses to prevailing environmental conditions. Pioneering work in East and southern Africa during the 1970s and 1980s studied the distributions of these plants in detail and laid the groundwork for their use as palaeoenvironmental proxies (Vogel et al. 1978; Tieszen et al. 1979). The strongest determinant for $\mathrm{C}_{4}$ plant distribution is growing season temperature (Ehleringer et al. 1997). Vogel et al. (1978) recorded the crossover maximum summer temperature for $\mathrm{C}_{4}$ biomass domination $(>50 \%)$ in southern Africa as at least $25^{\circ} \mathrm{C}$, below which $\mathrm{C}_{3}$ plants have greater success. In high-altitude areas, such as Lesotho or the highlands of Ethiopia, the result is an altitudinal transect, with $\mathrm{C}_{4}$ biomass increasing at lower, warmer altitudes, but being almost completely absent from colder, high-altitude locales (Tieszen et al. 1979; Livingstone and Clayton 1980; Smith et al. 2002).

In tropical contexts, $\mathrm{C}_{3}$ plants are frequently limited to forested and mixed woodlandgrassland ecologies, with $\mathrm{C}_{4}$ grasses and sedges found in more insolated, warmer grassland biomes (Cerling and Harris 1999). $\mathrm{C}_{4}$ plants are also at an advantage during conditions of lowered $\mathrm{pCO}_{2}$ (e.g. the Last Glacial Maximum), which must be taken into account when reconstructing palaeoenvironmental variables in the past (Ehleringer et al. 1997). Critically, for comparison between modern and pre-industrial datasets, the $\delta^{13} \mathrm{C}$ of modern atmospheric $\mathrm{CO}_{2}$ is now at least $2 \%$ more depleted than the $\delta^{13} \mathrm{C}_{\text {of }} \mathrm{CO}_{2}$ in the pre-industrial atmosphere (-6.5\%o) (Francey et al. 1999). Within the $\mathrm{C}_{3}$ plant group, environmental factors, including aridity, temperature, forest coverage and $\mathrm{CO}_{2}$ concentration can affect $\delta^{13} \mathrm{C}$ values and climatic interpretation (Tieszen 1991; van der Merwe and Medina 1991; Heaton, 1999; Kohn 2010).

These environmentally-driven variations in plant $\delta^{13} \mathrm{C}$ at the base of the foodchain are reflected in the stable isotope composition of faunal tissues, filtered by species' diet and behaviour. Africa has provided the principal setting for modern experiments establishing the reliability of faunal tissues, primarily the tooth enamel of herbivores, as indicators of past ecological conditions (Cerling and Harris 1999; Cerling et al. 1997, 2003, 2004; Codron et al. 2006; Levin et al. 2008). The relationship between diet and tissue stable isotope composition also underlies most stable isotope applications among archaeological human populations. However, the relationship is often more complex, with differences between $\delta^{13} \mathrm{C}$ of different bodily tissues (DeNiro and Epstein 1978; Passey et al. 2005) and distinctions between animals (and humans) depending on diet, physiology and behaviour (Lee-Thorp et al. 1989).

As dietary amino acids are preferentially incorporated into construction of proteinaceous tissues, $\delta^{13} \mathrm{C}$ values of tissues such as bone collagen preferentially reflect high protein sources such as animal foods (Ambrose and Norr 1993). On the other hand, bone and enamel mineral is formed in equilibrium with blood bicarbonate that are controlled by catabolic and respiratory processes (Krueger and Sullivan 1984; Passey et al. 2005); thus they reflect the entire, integrated diet. Thus among omnivorous humans, combined analyses of collagen and enamel or bone apatite, where preservation allows, can shed light on different components of the diet (Lee-Thorp et al. 1989; Ambrose et al. 1997; Harrison and Katzenberg 2003). 


\section{Stable nitrogen isotopes}

Stable nitrogen isotopes of plants reflect numerous environmental factors including soil type and $\delta^{15} \mathrm{~N}$, climate, nitrogen assimilation and nitrogen availability. However, the relationships are typically complex and non-linear (Heaton 1987; Handley and Raven 1992; Schmidt and Stewart 2003; Craine et al. 2015). Rainfall amount, in particular, has been frequently linked to plant $\delta^{15} \mathrm{~N}$. In a study of South African plants across regions with varying mean annual precipitation, Heaton (1987) identified a negative correlation between plant $\delta^{15} \mathrm{~N}$ and rainfall amount, associated with evaporative loss of ${ }^{15} \mathrm{~N}$-depleted ammonia from the soil, while Sealy et al. (1987) observed a similar relationship in herbivores along the west coast of South Africa. However, such relationships may be restricted to particularly arid ( $<400 \mathrm{~mm}$ mean annual precipitation) habitats. Using a far larger dataset of plants from the semi-arid Kruger National Park, South Africa, Codron et al. $(2005,2013)$ demonstrated a lack of correlation between plant $\delta^{15} \mathrm{~N}$ and rainfall.

Furthermore, even in contexts where a relationship between climate and plant $\delta^{15} \mathrm{~N}$ has been identified, the variety of animal gut physiologies and metabolic adaptations to water stress can obscure simple interpretation (Ambrose 1991; Sponheimer et al. 2003). As a result, $\delta^{15} \mathrm{~N}$ of animal and human hair and collagen is primarily used in ecological and archaeological studies to explore the trophic level of an individual or population. $\delta^{15} \mathrm{~N}$ values increase by 26\%o (mean ca $\sim 3 \%$ ) at every step in the food chain (DeNiro and Epstein 1981; Ambrose and DeNiro 1986; Sealy et al. 1987; O'Connell and Hedges 1999; Ambrose 2000). Considerable $\delta^{15} \mathrm{~N}$ variation is also reported within herbivores and Sponheimer et al. (2003) have demonstrated variation of up to $3.6 \%$ in experimental animals.

\section{Stable oxygen isotopes}

Terrestrial records of $\delta^{18} \mathrm{O}$ in the tropics and subtropics largely reflect hydrological conditions through isotope effects on precipitation and other sources of moisture (Dansgaard 1964; Gat 1996). Global patterns of $\delta^{18} \mathrm{O}$ in precipitation are primarily structured by temperature-dependent processes of evaporation from the oceans and by advection of moisture masses over the continents (Dansgaard 1964; Gat 1996). Fractionation affecting precipitation $\delta^{18} \mathrm{O}$ from these moisture sources is negatively influenced by temperature (cloud height and latitude) and by a rain-out or Rayleigh distillation effect that impacts on distance from the oceanic source ('continental effect') and an 'amount effect' related to heavy rain (Dansgaard 1964; Rozanski et al. 1993). Evaporation exerts a positive effect so that continental water bodies and soils in areas with a water deficit are ${ }^{18} \mathrm{O}$-enriched. In the tropics, lower rainfall $\delta^{18} \mathrm{O}$ is recorded in months with more rainfall and during intense events, while at mid-latitudes lower values occur in winter.

Further ${ }^{18} \mathrm{O}$ fractionation occurs as groundwater is utilised by plants and animals. The source water for plants is generally soil moisture, so part of the signal in plant $\delta^{18} \mathrm{O}$ is a sum of the isotope effects on soil water and no fractionation takes place in xylem transport within plants (Ehleringer and Dawson 1992). Evapotranspiration in leaves leads to preferential loss of ${ }^{16} \mathrm{O}$ and ${ }^{18} \mathrm{O}$ enrichment in the leaf (Gonfiantini et al. 1965). The magnitude of this effect is enhanced by low relative humidity (Flanagan et al. 1991; Barbour 2007). Since the leaf is the site of photosynthesis, and photosynthate products are used to construct the nonphotosynthetic plant parts such as wood, stems and fruits, the effects of evapotranspiration are effectively spread through the plant (McCarroll and Loader 2004). 
Over the last few decades, observations in African systems have improved our ability to interpret faunal tooth enamel $\delta^{18} \mathrm{O}$ values as environmental signals. $\delta^{18} \mathrm{O}$ of tooth enamel is determined largely by the oxygen isotope composition of ingested drinking and food water (Kohn 1996). Physiological and behavioural variables strongly influence body mass balance, however (Bocherens et al. 1996). In particular non-obligate and obligate drinkers (or 'evaporation sensitive' and 'evaporation non-sensitive' herbivores) differ strongly in their enamel $\delta^{18} \mathrm{O}$ values because the former obtain most of their water from plant sources and thus reflect primarily relative humidity. Levin et al. (2006) developed an 'aridity index' from such differences. A similar principle has been applied to ostrich eggshell in archaeological sites since ostriches are extremely water-independent (Johnson et al. 1997; Lee-Thorp and Ecker in press).

\section{Strontium isotopes}

Rather than tracking biological processes and relationships, strontium isotopes $\left({ }^{87} \mathrm{Sr} /{ }^{86} \mathrm{Sr}\right)$ reflect the geological context in which plants and their consumers grow and survive. A portion of naturally occurring ${ }^{87} \mathrm{Sr}$ derives from the decay of rubidium $\left({ }^{87} \mathrm{Rb}\right)$ so that ${ }^{87} \mathrm{Sr} /{ }^{86} \mathrm{Sr}$ ratios in any geological and soil context reflect both the concentration of rubidium and the age of the parent rocks (Faure and Powell 1972). Thus, ${ }^{87} \mathrm{Sr} /{ }^{86} \mathrm{Sr}$ values are patterned broadly according to geology. Strontium is incorporated into the food-chain through plants and into the calcified tissues of animal and human consumers as a substitute for calcium in biological apatite (Montgomery 2010). Strontium isotope measurements of tooth enamel can thus be used to track the residency of individuals during enamel formation. The period of time reflected varies depending on the tooth sampled, but broadly covers childhood and juvenile years in permanent human teeth. Analyses are restricted to enamel as a stable tissue because of the mobility of strontium in bones.

Natural strontium isotope variation can be subtle and differences in strontium reservoirs must be conservatively interpreted. Case studies of residence or movement are therefore sitespecific depending on the region of interest. Geological strontium maps may provide some indications, but the concept of 'bioavailable strontium' (strontium that is actually available to plants) is critical for interpretation of strontium variation in the ecosystem (Sillen et al. 1998). The processes of weathering, erosion and mixing that contribute to soil formation have been shown greatly to reduce the range of bioavailable ${ }^{87} \mathrm{Sr} /{ }^{86} \mathrm{Sr}$ compared to that of the parent geology; this dampening is not well-represented by a geological map (Sillen et al. 1998). Thus, studies of ${ }^{87} \mathrm{Sr} /{ }^{86} \mathrm{Sr}$ variation in archaeological contexts must be supported by assessments of local strontium isotope bioavailability determined from analyses of plants or locally resident animals (Sealy et al. 1991; Sillen et al. 1998; Copeland et al. 2010, 2011). Nevertheless, providing that results are interpreted conservatively, strontium isotope analysis has proven to be a powerful tool in studies of human migration and population movements (Sealy et al. 1995; Schroeder et al. 2009), faunal land-use practices (Balasse et al. 2002) and even the movement of biogenic artefacts (van der Merwe et al. 1990; Coutu 2015).

\section{Hunter-gatherer lifeways}

Stable isotope analysis has emerged as a fundamental methodology for investigating the palaeoclimatic and palaeoenvironmental contexts of human populations in Africa. In particular, such methods have been applied to identify intersections between climatic and environmental factors and technological and behavioural innovation among Middle and Later Stone Age (MSA and LSA) populations. 


\section{Environments of later modern humans during the Pleistocene}

A notable theme here is the identification of ecological constraints and opportunities that could have shaped the cultural trajectories of Homo sapiens. In MSA levels at Karungu near Lake Victoria, Kenya, Faith et al. (2015) demonstrated the presence of open $\mathrm{C}_{4}$ grasslands, where once there were thought to be only closed forests, allowing the possibility of northsouth migration opportunities for fauna and humans. This evidence helps to explain links between faunal and lithic assemblages from Karungu and sites to the north of the forest barrier, indicating that open grasslands may have facilitated an episode of human and animal population dispersal, against a backdrop of population isolation and fragmentation during closed-forest expansion.

Further south in the central interior of southern Africa, stable isotopes in fauna have proven particularly informative for detecting climate and temperature changes at a cluster of MSA and LSA sites that span a marked altitudinal and ecological gradient from the grasslands of the Caledon River Valley eastward into the Lesotho highlands. The relationship between growing season temperature and the proportions of $\mathrm{C}_{3} / \mathrm{C}_{4}$ plants, as recorded in the $\delta^{13} \mathrm{C}$ values of archaeological and natural sedimentary sequences, or in the enamel of grazing herbivores from these sites, is a proxy for past temperature shifts along an altitudinal transect (Vogel 1983; Smith et al. 2002; Parker et al. 2011; Roberts et al. 2013; Stewart et al. in press; Loftus et al. in press).

Records from sites including Rose Cottage Cave, Likoaeng, Ntloana Tšoana, Ha Makotoko, Melikane and Sehonghong, provide good evidence for sharp negative temperature excursions, particularly around the Pleistocene to Holocene transition that reflect both global-scale events such as the Younger Dryas Stadial (c. 12,800-11,500 BP: Loftus et al. in press) and even subsequent instability in the early Holocene (Smith et al. 2002; Roberts et al. 2013). These results are surprising because conditions in the Lesotho highlands can be challenging even today under relatively ameliorated conditions. Records of $\mathrm{C}_{3} / \mathrm{C}_{4}$ shifts from Sehonghong, Ntloana Tšoana and Ha Makotoko indicate late Pleistocene (Marine Isotope Stages 2 and 3) temperature shifts on the order of $3-5^{\circ} \mathrm{C}$ cooler than today (Smith et al. 2002; Roberts et al. 2013; Loftus et al. in press), suggesting profound effects on human ecosystems and resources.

\section{Late Holocene settlement and subsistence in South Africa}

Direct isotopic studies of African hunter-gatherer lifeways and diets are comparatively rare because of the scarcity of the physical remains of hunter-gatherers. The situation is not helped by warm and episodically wet conditions that are not conducive to preservation of bones. Only a few archaeological contexts, with exceptional organic preservation, have yielded sufficient numbers of skeletons to assess inter-population and temporal dietary variation. An excellent case study comes from late Holocene LSA archaeological sites in the southern and southwestern Cape regions of South Africa, where a long-standing debate concerns the scheduling of hunter-gatherer movements throughout the year. Based on multiple bioarchaeological lines of evidence and ethnographic analogies, John Parkington has proposed a model of seasonal mobility for the south west Cape region from c. 4000-2000 BP, with people moving between the interior and the coast to optimally exploit the seasonallyavailable resources across the different ecozones (Parkington 1972, 1976). In one of the earliest applications of stable carbon isotope analysis to archaeological humans, isotopic differences between people buried at the coast versus those buried in the interior suggested 
that the two areas were inhabited by separate populations that exploited distinct sets of dietary resources (Figure 3; Sealy and van der Merwe 1985, 1986, 1988). These data implied that populations were less mobile than previously thought and challenged prevailing fusionfission ideas of hunter-gatherer social and economic organisation, at least as suggested for South Africa's west coast.

This study was underpinned by a robust assessment of isotopic patterning among a wide range of the potential marine and terrestrial foods available to hunter-gatherers. Nevertheless, Sealy and van der Merwe's (1986) interpretation was disputed on a number of grounds, including the isotopic characterisation of potential foods such as underground storage organs and marine molluscs (Parkington 1991). Subsequent publication of the $\delta^{15} \mathrm{~N}$ values of the same group of hunter-gatherers revealed unsuspected complexity in dietary isotope patterning that would indeed have obscured the importance of particular food groups in certain environments. Despite the ${ }^{15} \mathrm{~N}$-enrichment typically observed in marine ecosystems due to longer foodchains (Schoeninger and DeNiro 1984), Sealy et al. (1987) demonstrated that certain low-trophic level marine foods, such as molluscs, can have more negative $\delta^{15} \mathrm{~N}$ signatures than terrestrial herbivores from areas with low mean annual rainfall, due to the effects of aridity on mammalian $\delta^{15} \mathrm{~N}$ values. Thus, in arid and semi-arid regions the diets of people consuming substantial amounts of low-trophic level marine foods could be more depleted in ${ }^{15} \mathrm{~N}$ than those of people eating an entirely terrestrial diet (Sealy et al. 1987).

In regions such as the southwestern Cape with low proportions of ${ }^{13} \mathrm{C}$-enriched $\mathrm{C}_{4}$ plants, more positive $\delta^{13} \mathrm{C}$ values among people distinguish diets with a high marine dietary contribution, but in coastal environments with a greater abundance of $\mathrm{C}_{4}$ plants, more positive $\delta^{13} \mathrm{C}$ can be interpreted as a large contribution of $\mathrm{C}_{4}$ plant or marine foods to the diet. Along the southern cape coast of South Africa, Sealy $(1997,2006)$ utilised $\delta^{13} \mathrm{C}$ and $\delta^{15} \mathrm{~N}$ values together to constrain the contributions of ${ }^{13} \mathrm{C}$-enriched terrestrial and marine foods. $\delta^{13} \mathrm{C}$ and $\delta^{15} \mathrm{~N}$ measurements of two populations indicate that while people living on and near the Robberg Peninsula from 4500-2000 BP were eating high-trophic level marine foods, most likely seals (Arctocephalus pusillus), people buried over the same time at the Matjies River rockshelter only $14 \mathrm{~km}$ along the coast did not. Before and after 4500-2000 BP, these hightrophic level foods appear not to have been as important in the diets of the people buried at the Robberg Peninsula/Plettenberg Bay sites. The isotopic differences between the two populations suggest the existence of territorial boundaries along this stretch of coastline, at least between 4500 and $2000 \mathrm{BP}$, with limited exchange or movement of people between the two regions.

The dietary and palaeoenvironmental studies discussed here point towards the ways in which stable isotope data can challenge some of the theoretical underpinnings of hunter-gatherer archaeology. For example, in Sealy (2006) the dietary shifts evident at 4500 BP and 2000 BP, which imply changes in settlement and social organisation, appear not to coincide with regional changes in technological organisation that are evident in the lithic assemblage at 3300 BP (Inskeep 1987). This discrepancy confronts long-held assumptions about the universality of the relationship between technology and subsistence. In Lesotho, meanwhile the accumulating palaeoenvironmental and archaeological data are now leaning towards an integrated theory of how technological innovations were operationalised by people across the region. They are at the forefront of wide-ranging discussions that seek to reinvigorate static descriptions of Late Pleistocene technological change across southern Africa (Loftus et al. in press). 


\section{Origins of food production}

Compared to classic Neolithisation models developed in regions such as southern Europe, the shift from foraging to food production was a comparatively patchy and drawn-out process across Africa, with hunter-gatherer, pastoralist and farming groups living alongside one another for millennia. The various modes of pastoralism, including loosely defined 'herding' strategies and agropastoralism, have been particularly important in the development of foodproducing societies in Africa, typically preceding intensive crop agriculture, and are still practised in many regions today. Despite the time-depth and prevalence of this way of life, variation in pastoralist strategies is not well understood. Stable isotope methods are contributing to questions both broad and specific in studies of pastoralism, for example, characterising the inputs of primary and secondary domesticated products to human diets (Lee-Thorp et al. 1993; Sealy 2010), discerning herd management and breeding strategies (Balasse et al. 2003; Smith et al. 2010) and reconstructing herd and human mobility across the landscape (Balasse et al. 2002; Tafuri et al. 2006; di Lernia and Tafuri 2013; di Lernia et al. 2013; Stojanowski and Knudson 2014).

\section{Antiquity of pastoralism in southern Africa}

Observations of indigenous Khoekhoe groups by early European travellers to the Cape reported that large herds of sheep and cattle were the mainstay of the Khoekhoe pastoralist economy and that, although sheep outnumbered cattle in these historical herds, the numbers of cattle were nonetheless substantial, with upwards of 10,000 cattle in a single herd. Yet, in archaeological investigations of prehistoric Cape pastoralist communities, the number of cattle bones is typically low, suggesting a more limited importance for cattle amongst the Khoekhoen, at least until the historical period (Sealy 2010). One interpretation is that the large herds observed by European travellers in the seventeenth and early eighteenth centuries developed in response to the demand for beef from those same Europeans (Sadr 1992; Sealy 2010). This contradiction intersects with questions regarding the timing and mechanisms of the spread of pastoralism into southern Africa. At issue here is how earlier pastoralist communities organised their societies and economies and how far back the historically observed Khoekhoe cultural emphasis on cattle extends into the past (see Orton 2015).

To address this debate, Sealy (2010) measured the $\delta^{13} \mathrm{C}$ and $\delta^{15} \mathrm{~N}$ values of bone collagen from the skeletons of hunter-gatherers and pastoralists, spanning the introduction of domesticated animals to southern Africa c. 2000 years ago until the beginning of intensive European contact, some 380 years ago. Upon the introduction of domesticates no significant shift in $\delta^{13} \mathrm{C}$ and $\delta^{15} \mathrm{~N}$ values is observed relative to the wide range of values for huntergatherers, consistent with interpretations that posit a limited dietary role for domesticated animals among these populations, at least initially: the 'hunters-with-sheep' scenario of Sadr (2004). However, after $c$. AD 1000 individuals reflect more positive $\delta^{13} \mathrm{C}$ relative to $\delta^{15} \mathrm{~N}$, indicating a greater proportion of $\mathrm{C}_{4}$-based terrestrial foods in their diet. Sealy suggests that the most likely driver of this shift was the inclusion of greater amounts of dairy products from $\mathrm{C}_{4}$-grazing cattle after $1000 \mathrm{BP}$, although isotopic approaches themselves cannot directly distinguish whether dairy or other cattle products, such as blood or meat, underlie the shift. While the study is limited by small sample sizes and the precision of the available radiocarbon dates, Sealy integrates the isotopic evidence with that from burials, craniometric studies and rock art to demonstrate the precolonial antiquity of cattle pastoralism in southern Africa. 
Studies of the diets and mobility of domestic animals can also provide details about herd management that are not accessible by any other means. Balasse et al. (2002, 2003), for example, sampled the teeth of sheep and cattle at high resolution to ascertain how pastoralist strategies among precolonial herders may have differed from those observed in historical periods. Early European travellers to southern Africa observed that indigenous pastoralists maintained large herds of sheep and cattle by moving seasonally between coastal and inland pastures. Balasse et al. (2002) serially sampled $\delta^{13} \mathrm{C}$ and ${ }^{87} \mathrm{Sr} /{ }^{86} \mathrm{Sr}$ values in sheep and cattle teeth from the first-millennium $\mathrm{AD}$ herding site of Kasteelberg in the southwestern Cape to reveal intra-annual scale records of diet over several years of life. Figure 4 shows the $\delta^{13} \mathrm{C}$ and ${ }^{87} \mathrm{Sr} /{ }^{86} \mathrm{Sr}$ results of two sheep and one cow and the three teeth reveal three different trends in ${ }^{87} \mathrm{Sr} /{ }^{86} \mathrm{Sr}$, each consistent with different settlement patterns. The first sheep reflects ${ }^{87} \mathrm{Sr} /{ }^{86} \mathrm{Sr}$ ratios from both coastal and inland regions, while the second reflects an entirely coastal geological signal. The cow molar ${ }^{87} \mathrm{Sr} /{ }^{86} \mathrm{Sr}$ entirely reflects the geology of the interior, although its bones were found at the coast. This variation among only three animals suggests that the historically observed pattern of seasonal mobility may have developed sometime after the first-millennium AD occupation of Kasteelberg.

\section{Pastoralism in the Sahara}

The antiquity of dairying in the Sahara is well established (Dunne et al. 2012) and several stable isotope studies have investigated pastoralist lifeways in this marginal environment, most notably using ${ }^{87} \mathrm{Sr} /{ }^{86} \mathrm{Sr}$ through the lens of mobility. In southwestern Libya, Tafuri et al. (2006) analysed enamel and, in some cases, bone ${ }^{87} \mathrm{Sr} /{ }^{86} \mathrm{Sr}$ ratios for 35 people from a number of archaeological sites spanning several thousand years, from the hunter-gatherer Acacus period (c. $8500 \mathrm{BP}$ ) through the Pastoral phases (c. 7000-2500 BP) and into the Garamantian civilisation (c. $1000 \mathrm{BC}$ to $\mathrm{AD} 600)$. Although sample sizes are small, ${ }^{87} \mathrm{Sr} /{ }^{86} \mathrm{Sr}$ variation is greater both before and after the Pastoral periods, i.e. among both hunter-gatherer and Garamantian populations, with a more restricted range of ${ }^{87} \mathrm{Sr} /{ }^{86} \mathrm{Sr}$ values during the Pastoral periods. The restricted range among pastoralists is consistent with a structured and regular mobility schedule, possibly on a seasonal basis, that averaged the strontium isotopic variability encountered. Subsequent analyses of faunal $\delta^{18} \mathrm{O}, \delta \delta^{13} \mathrm{C}$ and ${ }^{87} \mathrm{Sr} /{ }^{86} \mathrm{Sr}$ (di Lernia et al. 2013) indicated that herds were maintained by seasonal migration between regional pastures.

In central Niger, Stojanowski and Knudson $(2011,2014)$ have explored the importance of the Gobero palaeo-lake to both hunter-gatherer-fisher peoples during the Early Holocene climatic optimum and a subsequent population that may have practised transhumant cattle pastoralism under the increasingly arid conditions of the mid-Holocene. They interpreted the narrow range of ${ }^{87} \mathrm{Sr} /{ }^{86} \mathrm{Sr}$ values as implying a high degree of sedentism among the hunter-gathererfisher population (Stojanowski and Knudson 2011) in contrast to greater variability in the pastoralist population, which was perhaps influenced by the nearby Aïr Massif (Stojanowski and Knudson 2014). Thus, during the mid-Holocene, people apparently ranged more widely outside of the Gobero palaeo-lake basin, possibly as a response to the increasing aridity of this period. It should be noted that problems of interpretation arise not only due to small sample sizes in these studies, but also because of regional patterning in geological ${ }^{87} \mathrm{Sr} /{ }^{86} \mathrm{Sr}$ signals. There is evidently considerable overlap in values across the geological formations in the Libyan studies (see di Lernia and Tafuri 2013: Figure 8a) and regional strontium bioavailability is not yet well-mapped in the study areas (Tafuri et al. 2006; di Lernia and Tafuri 2013; Stojanowski and Knudson 2014). The effect of modern desert dust, which 
homogenises bioavailable strontium, represents a considerable impediment for such geosourcing studies in desert zones.

The studies described above suggest many further applications of stable isotope techniques to studies of pastoralism that may better characterise the variability of this way of life across Africa. Dietary studies can explore differential access to animal products among social groupings: Ambrose (1986; Ambrose and DeNiro 1986) first demonstrated that $\delta^{13} \mathrm{C}$ and $\delta^{15} \mathrm{~N}$ analyses of collagen could distinguish a range of subsistence strategies, including camel and capri-bovine pastoralism and grain and non-grain farming among modern African pastoralists and farmers. Combined analyses of bone collagen and bone apatite $\delta^{13} \mathrm{C}$ further discriminated between low- and high-protein diets among Kenyan herders and farmers as the difference in $\delta^{13} \mathrm{C}$ of the two tissues reflects the proportion of dietary protein (Ambrose 1993). Another promising direction of study, given current understandings of the complex pathways to animal domestication throughout Africa, is the diffusion of pastoralism among different groups throughout the continent. Better understandings of the timing and mechanisms of diffusion will lead to improved framings of the regional ecological and historical impacts of pastoralist communities in the past and in the present (e.g. Ellis et al. 2013; Lambin et al. 2001).

\section{States and hierarchy}

Improved archaeological visibility and organic preservation provides greater opportunities for isotopic studies among state-level societies and the profound shifts in economy and subsistence that typically accompany the development of complex societies lend themselves to exploration with stable isotope studies of human diet, dependant on the availability of skeletal remains (Lee-Thorp et al. 1993; Murphy 2011). A central focus of research programmes lies in understanding how state-level societies have managed their lands and herds, particularly in the face of the unpredictable environmental conditions that make farming so challenging across large parts of Africa (White 1993; White and Schwarcz 1994; White et al. 1999; Smith et al. 2007, 2010). The stable isotope investigations discussed below improve understandings of the social responses among states and peripheral communities to changing economic pressures that result from climatic and ecological shifts (Gebru et al. 2009; Marshall et al. 2009; Smith et al. 2007, 2010; Terwilliger et al. 2011).

\section{Farming and social complexity}

The African Iron Age is a broad cultural designation linking groups of settled farming peoples. In eastern and southern Africa, the Iron Age is associated with Bantu speakers, who spread initially out of West Africa with the Iron Age 'package' of metal tools, ceramics, grains and cattle (Huffman 1982). Much of the research in the field has focused on the genetic identity of these groups and the timing of their dispersal across the sub-continent. The arrival of Iron Age material culture in various regions of Africa has been associated with major changes in economic organisation, social stratification and political control. Stable isotope studies can explore the impact of these changes on groups, by accessing details of diet and environment that are often unavailable from other methods. Of particular interest is the development of intensive crop agriculture, which has substantially transformed landscapes and societies across Africa.

Nevertheless, isotopic dietary studies of Iron Age populations in Africa are rare and most information about the diets of farmers still comes from standard archaeological lines of 
evidence. This is despite the fact that plant foods are known to be under-represented in archaeological sites due to their poor preservation. Archaeologists have long recognised that the preponderance of cattle bones in many Iron Age archaeological sites may not relate to their dietary importance, given the symbolic and social significance of cattle among Iron Age communities (Hall 1986). However, the near invisibility of plant remains in the archaeological record has muddied assessments of the changing importance of crops versus livestock among different Iron Age communities (Ambrose 1986; Ambrose and DeNiro 1986; Lee-Thorp et al. 1993).

Lee-Thorp et al. (1993) measured $\delta^{13} \mathrm{C}$ and $\delta^{15} \mathrm{~N}$ of 47 farmers and 14 pastoralist/mixedfarming people spanning six ecological zones across a broad swathe of the southern African summer-rainfall area to investigate the importance of crops in Iron Age diets. Their study detected several interesting trends, including a high degree of isotopic variability compared to other farming groups globally and patterning between ecological conditions and the importance of livestock versus crops. These data speak to a greater flexibility in economic practice than was previously realised, in contradiction to assumptions of cultural or economic uniformity across these communities.

In addition, Lee-Thorp et al. observed differences in animal-product consumption that patterned with political stratification, with people living at larger sites consuming more animal protein than people living at smaller sites, lower down the political hierarchy. More recently, Murphy (2011) has sought to address similar questions about the relative dietary importance of crops and livestock among people living in contemporaneous sites with varying degrees of political capital in the Toutswe region of Botswana. Although limited by small sample sizes, low $\delta^{15} \mathrm{~N}$ values compared to those of modern African pastoralist groups suggest that plant foods played an important role in the diets of these people. Moreover, the results hint at dietary differences between people living at sites that vary in regional political importance, suggesting a promising route for future investigations.

\section{States, climate change and ecological management}

Another avenue of developing stable isotope research probes the relationship between climate change and African state-level organisation (Gebru et al. 2009; Marshall et al. 2009). Causes behind the emergence and fall of state level societies are hotly debated and popular in the context of our own political, economic and social relationships with the world's climate (e.g. Büntgen et al. 2011; Kennett et al. 2012). These questions have stimulated the use of stable isotopes to reconstruct regional and local palaeoenvironmental records in association with the Aksumite empire in Ethiopia and Eritrea $c$. AD 100-940. Growing since the fourth century $\mathrm{BC}$, Aksum was among the four most powerful commerical empires of the Old World by AD 200, prior to its economic stagnation and de-centralisation $c$. AD 800 (Butzer 1982; Bard et al. 2000).

A diatom and stable oxygen isotope record from Lake Ashenge sediments suggest that a wet period at the beginning of the Christian era stimulated the expansion of Aksum's agricultural production at this time (Marshall et al. 2009). A more local stable carbon and nitrogen palaeoenvironmental record from gully walls bordering the Aksumite empire's expanse was taken as confirmation of this (Terwilliger et al. 2011). However, Gebru et al. (2009) and Terwilliger et al. (2011) have also argued that these records could be indicative of human land clearance rather than climatic impacts. These studies confront the same issue as many similar attempts to link climate to human behaviour, namely to what extent can climatic and 
environmental changes at different scales be definitively linked with human behaviour? That said, the palaeoenvironmental reconstructions on both regional and local scales that have been attempted here are an advance in this regard.

The processes of growth and decline that affect a large state society, and their intersection with climate change and economic organisation, have also been studied in detail in southern Africa around the rise of the kingdom of Zimbabwe. The period between AD 880 and 1290 saw a rapid rise in the socio-political complexity of the Iron Age farming communities in the Shashe-Limpopo River Basin and the broader region (Huffman 2000). This process was accompanied by an estimated ten-fold increase in population and the development of an hierarchical, class-based bureaucracy with a sacred leadership, prior to the sudden abandonment of the capital Mapungubwe $c$. 1290. A leading analysis of the archaeological sequence has emphasised a prolonged period of drought as a primary cause of the polity's 'collapse' (Huffman 1996), but this interpretation is inconsistent with palaeoenvironmental proxies from the region, including pollen cores (Scott et al. 2003) and stalagmite records (e.g. Lee-Thorp et al. 2001).

To explore the environmental and agricultural conditions within the Shashe-Limpopo Basin itself, Smith et al. (2007) analysed the $\delta^{15} \mathrm{~N}$ signals of cattle and ovicaprids from multiple sites, as a proxy for rainfall levels, across the entire period of settlement. On the basis of modern $\delta^{15} \mathrm{~N}$ measurements from domesticated and wild herbivores across a regional rainfall gradient they identified a series of wetter and drier phases in the archaeological data across the period in question. However, they found no evidence that the collapse of Mapungubwe and regional depopulation occurred during an especially dry period (contra Huffman 1996, 2009). Their results indicate that agropastoral success or the converse, polity collapse, was unlikely to be determined by climatic factors, leaving socio-political drivers to be explored. These may have included population expansion or shifts in lucrative trade routes with consequent diminishment of economic power. To establish how agropastoral strategies may have accommodated population increases, Smith et al. (2010) measured the ${ }^{87} \mathrm{Sr} /{ }^{86} \mathrm{Sr}$ values of cattle and caprine teeth from several sites spanning the late first and early second millennia $\mathrm{AD}$ in order to reconstruct intra-annual herding strategies. Results indicate that herding was more far-ranging during the occupation of Mapungubwe than in preceding phases. The authors hypothesise that greater numbers of people on the landscape decreased productivity, feeding political instability in a society in which agricultural productivity was increasingly invested in the sacred powers of the ruling élite. Consequently, these declines were offset by the strategic movements of herds between different pastures on a seasonal basis.

Responses to climatic conditions within state-level societies can also be assessed isotopically by tracking human diet directly through time and within social groups. Over millennia of farming along the Nile and in the oases of Egypt, people have developed technological and behavioural strategies to cope with the challenging seasonal variation and general water scarcity. The extreme desiccating conditions at these sites have naturally mummified the remains of ancient peoples, with the preservation of soft tissues including flesh and hair permitting exceptionally detailed investigations of individual life-histories (White 1993; White and Schwarcz 1994; White et al. 1999; Schwarcz and White 2004). Serial isotopic analyses of hair reveal dietary inputs over the period of growth, reflecting intra-annual changes in diet. For example, White (1993) analysed the hair of 14 individuals from Lower Nubian sites in the Wadi Halfa area along the Nile, and showed that modern seasonal crop rotation strategies, with water-intensive $\mathrm{C}_{3}$ crops grown during the wetter winter months, switching to hardier $\mathrm{C}_{4}$ crops during the water-restricted summer months, were practised 
from the introduction of intensive agriculture to the region. A subsequent study from contemporaneous Egyptian mummies of the Kharga Oasis, less affected by seasonal fluctuations in water availability, revealed little input of $\mathrm{C}_{4}$ foods to the diet at any time of the year, consistent with a seasonally uniform diet (White et al. 1999).

A good deal of the history of centralised state societies in Africa, based on isotopic methods, remains comparatively unexplored with respect to other parts of the world, such as Mesoamerica or the south-central Andes. In many contexts, little is known of the daily functioning of ancient complex societies, contributing to an impression of economic and social homogeneity among African cultural groupings. The lives of people living on the peripheries of the large centres of powers are particularly obscure. More nuanced understandings are nevertheless possible, not least through the application of stable isotope methods, as demonstrated by some of the relatively small, but promising studies discussed above. A promising route for understanding the full scope of African Iron Age behaviours in a global context is the systematic recovery of crop remains using flotation techniques (e.g. Boivin et al. 2014). Innovative stable isotope studies in Europe, Southwest Asia and other regions that incorporate archaeological crop remains (e.g. AGRICURB, www.agricurb.com) have demonstrated the wide scope of questions that can be explored with a combination of palaeobotanical and stable isotope studies, including land management practices, processes of agricultural extensification/intensification and urbanisation.

\section{Individual life-histories and the slave trade}

In addition to addressing broad questions about social change, stable isotope techniques can assist with detailed life-history reconstructions at the scale of the individual, using highresolution, serial or multi-tissue sampling strategies that exploit the differential timing of growth of various skeletal elements. Teeth form during the early stages of life, typically within the first few years for many species, and do not undergo remodelling once completely mineralised. For example, among humans, enamel captures the dietary inputs during infancy and childhood, with the third molars completely mineralising by late adolescence. Bone, however, remodels throughout life, gradually replacing the constituent molecules. Thus, bone typically reflects the aggregated diet of the final years of life, although rates of turn-over vary through life and between dense and cancellous (spongy) bone.

These differences in timing and tempo of growth provide a means of assessing changes in diet and mobility between early and late life. Some of the earliest and most successful applications of these principles have been in studies of African individuals experiencing forced migration under conditions of slavery. Despite, or perhaps because of, the enormous scale of the slave trade, the identity and origins of individual slaves is known only in rare instances. Records of transactions involving slaves typically detail only the ports and coastal areas in Africa where the slaves were shipped from, and not their ethnic groups or the inland regions where they were captured. With increasing social and cultural anthropological interest in the stories of forced migrants, geochemical techniques, including isotopic and genetic studies (e.g. Bryc et al. 2010), are employed to reveal additional details of individual life-history.

In the Cape region of southern Africa, excavations at the eighteenth-century slave lodge of a large estate, Vergelegen, uncovered the poorly-preserved skeleton of an adult woman who suffered from severe arthritis. In a pioneering study, the body was analysed in great detail using several methods to reveal particular events in the life of this woman, who was very 
likely a slave. $\delta^{13} \mathrm{C}$ and $\delta^{15} \mathrm{~N}$ analyses of teeth and bone samples from the rib and femur revealed a marked change in diet between childhood and adulthood, with a probable increase of marine foods in her adult diet (Sealy et al. 1993, 1995). The ${ }^{87} \mathrm{Sr} /{ }^{86} \mathrm{Sr}$ ratios of her bones, formed during the later years of her life, are consistent with local geological values, while those of her teeth are markedly higher, indicating that her childhood was very likely not spent at the Cape. This is consistent with her enslavement during early adulthood somewhere outside of the Cape, while after her transportation there her diet included greater amounts of fish, a low-status food frequently given to slaves.

Subsequently, Cox and Sealy (1997) attempted to identify the origins of eight individuals excavated from Fort Knokke in Cape Town. These individuals, mostly children and young adults, were suspected to have been slaves based on intentional modifications to their teeth by filing and chipping, a practice widely observed among African ethnic groups in south-central Africa but not among more southerly groups. In all cases, the $\delta^{13} \mathrm{C}$ values of bones with a fast turnover rate, such as ribs, were higher than those from dentine or cortical bones (which remodel only slowly), indicating that these individuals underwent a change in diet shortly before death. In conjunction with ethnographic comparisons of tooth modifications and historic accounts of slaver shipwrecks at Fort Knokke, Cox and Sealy (1997) identified the individuals as very likely being slaves en route from Mozambique to Brazil on the Pacquet Real, which wrecked at the Cape in 1818.

Isotopic studies are also helping to trace the movements of enslaved Africans even further afield, in Mexico (Price et al. 2006, 2012), New York (Goodman et al. 2004) and Barbados (Schroeder et al. 2009). Schroeder et al. (2009), for example, analysed the ${ }^{87} \mathrm{Sr} /{ }^{86} \mathrm{Sr}$ and $\delta^{18} \mathrm{O}$ signatures of different tissues from 25 individuals buried in a plantation slave cemetery on Barbados, dating to between the late seventeenth and early nineteenth centuries (see the tooth enamel results in Figure 5). They identified seven people whose ${ }^{87} \mathrm{Sr} /{ }^{86} \mathrm{Sr}$ ratios differed from that of the regional geology, suggesting that these individuals were born in Africa, but in at least three different regions. Notably, only two of these individuals had dental modifications, considered to be a marker of African-born individuals as the practice appears to have rapidly died out in the New World, and the isotope analyses identify more African-born individuals than relying on the presence of dental modifications alone. Their data also reveal life-history details, including the fact that at least one of the individuals studied was transported to Barbados as a child, as ${ }^{87} \mathrm{Sr} /{ }^{86} \mathrm{Sr}$ values differ between the early-forming first molar and laterforming third molar.

\section{Discussion and conclusions}

In the above examples we have not attempted to provide a complete list of archaeological stable isotope studies in Africa, nor even a list of the entire variety of applications available to African archaeologists seeking to involve stable isotope research in their projects. We have instead presented those research areas that have witnessed immensely successful and diverse contributions of stable isotopic analysis in the study of African human palaeoenvironments, diets, mobility and social change. In doing so, these examples also illustrate the two main elements of African archaeology's relationship with stable isotope analysis to date. The continent has witnessed a huge increase in the intensity and variety of the application of this methodology to different regions, periods and archaeological questions, as well as increased understanding of stable isotopic variation, and complexity, in modern ecological systems. However, there also remains great inequality in the spread of these studies across Africa. 
While southern and East Africa can boast a wealth of stable isotopic publications across the span of human and hominin history, other regions remain relatively unexplored.

Researchers have also had to confront numerous practical and taphonomic considerations, not least due to the nature and age of many African archaeological contexts. Technical advances have driven the rapid growth of what was once a highly specialised field: measurements of carbon, nitrogen and oxygen isotope ratios are cheaper and simpler than ever. Still, many countries around the continent have limited access to laboratories, funding and training. Moreover, the kinds of preservation contexts and archaeological sites in Africa, particularly the dearth of cemeteries, often result in small, incomplete and locally variable datasets when compared to other regions of the world. These issues of preservation and small datasets can, however, be offset by methodological refinements and improved understandings of natural variation (Von Schirnding et al, 1982; Lee-Thorp et al. 1987, 1989; Sponheimer and LeeThorp 1999; Balasse et al. 2002, 2003; Loftus and Sealy 2012; Sandberg et al. 2014), as well as by the innovative development of well-framed, answerable archaeological questions.

The contradiction of Africa's seminal role in the development of stable isotope analysis as an archaeological specialism and its patchy application to date is, in part, a result of the uneven distribution of expertise and financial and laboratory resources. Furthermore, the perceived impenetrability of stable isotope methods, and, to some degree, the real world complexity of natural stable isotope systems, has somewhat ring-fenced the specialism as being separate from mainstream archaeology, especially in those regions lacking a history of stable isotope research. Happily, emerging research in North and Central Africa, some of which has been presented here, suggests that such a divide is not permanent. Moreover, increased collaboration between archaeologists and stable isotope specialists is beginning to result in more integrated projects across Africa that incorporate these methodological components at the design phase, rather than as specialist 'add-ons,' thus providing more than simply a veneer of scientific endeavour.

Integrated stable isotope research is particularly essential as the techniques themselves continue to develop. Increased application and refinement of sequential stable isotope analysis of archaeological materials is beginning to provide unexpected levels of resolution regarding human palaeoclimates, palaeoecologies and palaeodiets. For example, sequential/serial sampling of faunal tooth enamel is enabling hunting strategies and pastoral management to be resolved down to movement across seasons and between localities. A similar resolution of sampling, and the increasing role of chronological specialists in multidisciplinary research programmes, offers the potential for high-resolution palaeoenvironmental records of immediate relevance to human terrestrial and marine ecologies ranging from historical periods back through the LSA and MSA. Communication between archaeologists and stable isotope specialists, from the commencement of excavation to the final publication stage, can only increase the potential of stable isotopic datasets to yield new, powerful insights to cultural, social and economic questions in human prehistory that were previously considered impenetrable.

Yet, as stable isotope research across Africa has demonstrated for nearly four decades now, modern comparative isotope data are, and will remain, critical for the interpretation of archaeological datasets, providing the linkages to connect complex series of environmental processes, operating on a broad range of spatial and temporal scales, to the final isotopic archive. Stable isotope research questions in archaeology must, for each region and period, factor in whether it is feasible to isotopically resolve resource differences of interest to 
relevant palaeodietary questions, to determine the key climatic parameters driving a stable isotopic palaeoenvironmental record or to isotopically distinguish different geological regions and localities of interest in the context of faunal or human mobility. In many cases, especially in regions relatively untouched by the specialism, datasets that can enable such decisions to be made do not yet exist. As a result, stable isotope research in African archaeology will continue to be driven by an expansion of isotopic understanding in the present as much as it is by the diversity and time-depth of potential applications in the past.

\section{Notes}

${ }^{1}$ Isotope abundances are reported in the $\delta$ notation, relative to international standards of known isotopic composition. Because differences in natural systems are subtle, values are expressed in parts per thousand or per mille (\%o ) as follows:

$$
\delta^{\mathrm{a}} \mathrm{X}=\left\{\mathrm{R}_{\text {sample }} / \mathrm{R}_{\text {standard }}-1\right\} \times 1000
$$

where $\mathrm{R}_{\text {sample }}$ is the ratio of ${ }^{\mathrm{a}} \mathrm{X}$ (the more abundant isotope) to ${ }^{\mathrm{b}} \mathrm{X}$ of the sample material and $\mathrm{R}_{\text {standard }}$ is that of a standard reference material. For carbon isotopes the standard to which all others are pegged is Peedee Belemnite (PDB), a marine fossil. As marine carbonates are relatively enriched in ${ }^{13} \mathrm{C}$ compared to other biological materials, the $\delta^{13} \mathrm{C}$ values of most organic materials are negative.

\section{Notes on contributors}

Emma Loftus is a doctoral student in Archaeological Science at the University of Oxford. She investigates Pleistocene and Holocene sea surface temperature seasonality to explore the intersections between climatic and archaeological change during the Middle and Later Stone Age in southern Africa.

Patrick Roberts is a doctoral student in Archaeological Science at the University of Oxford. His research focuses on using stable isotope analysis of human and faunal fossil remains to elucidate Late Pleistocene human rainforest adaptations in Sri Lanka. He has also used stable isotope analysis of archaeological and palaeontological remains as a means of palaeoenvironmental and dietary reconstruction in East and South Africa, Europe and Saudi Arabia.

Julia Lee-Thorp is Professor of Archaeological Science at the University of Oxford. She is a graduate of the University of Cape Town and an expert in stable isotope applications within archaeology and ecology. Her research career has spanned the full temporal range in African palaeoanthropology and archaeology, focussed on diet, and palaeoclimates and environments.

\section{References}

Ambrose, S.H. 1986. "Stable carbon and nitrogen isotope analysis of human and animal diet in Africa". Journal of Human Evolution 15: 707-731.

Ambrose, S.H. 1991. "Effects of diet, climate and physiology on nitrogen isotope abundances in terrestrial foodwebs." Journal of Archaeological Science 18: 293-317. 
Ambrose, S.H. 1993. "Isotopic analysis of palaeodiets: methodological and interpretive considerations." In Investigations of Ancient Human Tissue, edited by M.K. Sandford, 59-130. Langhorne: Gordon and Breach Science Publishers.

Ambrose, S.H. 2000. "Controlled diet and climate experiments on nitrogen isotope ratios of rats." In Biogeochemical Approaches to Palaeodietary Analysis, edited by S.H. Ambrose and M.A. Katzenburg, 243-259. New York: Kluwer Academic/Plenum Press.

Ambrose, S.H. and DeNiro, M. 1986. "Reconstruction of African human diet using bone collagen carbon and nitrogen isotope ratios." Nature 319: 321-324.

Ambrose, S.H. and Norr, L. 1993. "Experimental evidence for the relationship of the carbon isotope ratios of whole diet and dietary protein to those of bone collagen and carbonate." In Prehistoric Human Bone, edited by J. Lambert and G. Grupe, 1-37. Berlin: Springer-Verlag.

Balasse, M., Ambrose, S.H., Smith, A.B. and Price, T. 2002. "The seasonal mobility model for prehistoric herders in the south-western Cape of South Africa assessed by isotopic analysis of sheep tooth enamel." Journal of Archaeological Science 29: 917-932.

Balasse, M., Smith, A.B., Ambrose, S.H. and Leigh, S.R. 2003. "Determining sheep birth seasonality by analysis of tooth enamel oxygen isotope ratios: the Later Stone Age site of Kasteelberg (South Africa)." Journal of Archaeological Science 30: 205-215.

Barbour, M.M. 2007. "Stable oxygen isotope composition of plant tissue: a review." Functional Plant Biology 34(2): 83.

Bard, K.A., Coltort, M., DiBlasi, M.C., Dramis, F. and Fattovich, R. 2000. "The environmental history of Tigray (Northern Ethiopia) in the middle and late Holocene: a preliminary outline." African Archaeological Review 17: 65-86.

Bocherens, H., Koch, P.L., Mariotti, A., Geraads, D. and Jaeger, J.-J. 1996. "Isotopic biogeochemistry $\left({ }^{13} \mathrm{C},{ }^{18} \mathrm{O}\right)$ of mammal enamel from African Pleistocene hominid sites: implications for the preservation of paleoclimatic signals." Palaios 11: 306-318.

Boivin, N., Crowther, A., Prendergast, M. and Fuller, D.Q. 2014. "Indian Ocean food globalisation and Africa." African Archaeological Review 31: 547-581.

Bryc, K., Auton, A., Nelson, M.R., Oksenberg, J.R., Hauser, S.L., Williams, S., Froment, A., Bodo, J.-M., Wambebe, C., Tishkoff, S.A. and Bustamante, C.D. 2010. "Genome-wide patterns of population structure and admixture in West Africans and African Americans." Proceedings of the National Academy of Sciences of the United States of America 107: 78691.

Büntgen, U., Tegel, W., Nicolussi, K., McCormick, M., Frank, D., Trouet, V., Kaplan, J.O., Herzig, F., Heussner, K-U., Wanner, H., Luterbacher, J. and Esper, J. 2011. "2500 years of European climate variability and human susceptibility." Science 331: 578-582.

Butzer, K.W. 1982. "Empires, capitals and landscapes of ancient Ethiopia." Archaeology 36: 29-37. 
Cerling, T.E. and Harris, J.M. 1999. "Carbon isotope fractionation between diet and bioapatite in ungulate mammals and implications for ecological and paleoecological studies." Oecologia 120: 347-363.

Cerling, T.E., Harris, J.M., Ambrose, S.H., Leakey, M.G. and Solounias, N. 1997. "Dietary and environmental reconstruction with stable isotope analyses of herbivore tooth enamel from the Miocene locality of Fort Ternan, Kenya." Journal of Human Evolution 33: 635-650.

Cerling, T.E., Harris, J.M., Leakey, M.G. and Mudida, N. 2003. "Stable isotope ecology of northern Kenya with emphasis on the Turkana Basin." In Lothagam: The Dawn of Humanity, edited by M.G. Leakey and J.M. Harris, 583-603. New York: Columbia University Press.

Cerling, T.E., Harris, J.M., Leakey, M.G., Passey, B.H. and Levin, N.E. 2010. Stable carbon and oxygen isotopes in East African mammals: modern and fossil. In Cenozoic Mammals of Africa, edited by L. Werdelin and W. Sanders, 941-952. London: University of California Press.

Cerling, T.E., Harris, J.M. and Passey, B.H. 2004. Diets of East African Bovidae based on stable isotope analysis. Journal of Mammalogy 84: 456-470.

Codron, D., Lee-Thorp, J.A., Sponheimer, M., de Ruiter, D. and Codron, J. 2006. "Inter- and intrahabitat dietary variability of chacma baboons (Papio ursinus) in South African savannas based on fecal $\delta^{13} \mathrm{C}, \delta^{15} \mathrm{~N}$, and \%N." American Journal of Physical Anthropology 129: 204214.

Codron, J., Codron, D., Lee-Thorp, J.A., Sponheimer, M., Bond, W.J., de Ruiter, D.J. and Grant, R. 2005. "Taxonomic, anatomical, and spatio-temporal variations in the stable carbon and nitrogen isotopic compositions of plants from an African savanna." Journal of Archaeological Science 32: 1757-1772.

Codron, J., Lee-Thorp, J.A., Sponheimer, M. and Codron, D. 2013. "Plant stable isotope composition across habitat gradients in a semi-arid savanna: implications for environmental reconstruction." Journal of Quaternary Science 28: 301-310.

Cohen, A.L., Parkington, J.E., Brundrit, G.B. and van der Merwe, N.J. 1992. "A Holocene marine climate record in mollusc shells from the southwest African coast." Quaternary Research 38: 379-385.

Copeland, S.R., Sponheimer, M., de Ruiter, D.J., Lee-Thorp, J.A., Codron, D., le Roux, P.J., Grimes, V. and Richards, M.P. 2011. "Strontium isotope evidence for landscape use by early hominins." Nature 474: 76-78.

Copeland, S.R., Sponheimer, M., Lee-Thorp, J.A., le Roux, P.J., de Ruiter, D.J. and Richards, M.P. 2010. "Strontium isotope ratios in fossil teeth from South Africa: assessing laser ablation MC-ICP-MS analysis and the extent of diagenesis." Journal of Archaeological Science 37: 1437-1446.

Coutu, A. N. 2015. "The elephant in the room: mapping the footsteps of historic elephants with big game hunting collections." World Archaeology 47: 486-503. 
Cox, G. and Sealy, J.C. 1997. "Investigating identity and life histories: isotopic analysis and historical documentation of slave skeletons found on the Cape Town foreshore, South Africa." International Journal of Historical Archaeology 1: 207-224.

Craig, H. 1953. "The geochemistry of the stable carbon isotopes." Geochimica et Cosmochimica Acta 3: 53-92.

Craine, J.M., Brookshire, E.N.J., Cramer, M.D., Hasselquist, N.J., Koba, K., Marin-Spiotta, E. and Wang, L. in press. "Ecological interpretations of nitrogen isotope ratios of terrestrial plants and soils." Plant and Soil.

Dansgaard, W., 1964. "Stable isotopes in precipitation.” Tellus 16: 436-468.

DeNiro, M.J. and Epstein, S. 1978. "Influence of diet on the distribution of carbon isotopes in animals." Geochimica et Cosmochimica Acta 42: 495-506.

DeNiro, M.J. and Epstein, S. 1981. "Influence of diet on the distribution of nitrogen isotopes in animals." Geochimica et Cosmochimica Acta 45: 341-351.

di Lernia, S. and Tafuri, M.A. 2013. "Persistent deathplaces and mobile landmarks: the Holocene mortuary and isotopic record from Wadi Takarkori (SW Libya)." Journal of Anthropological Archaeology 32: 1-15.

di Lernia, S., Tafuri, M.A., Gallinaro, M., Alhaique, F., Balasse, M., Cavorsi, L., Fullagar, P.D., Mercuri, A.M., Monaco, A., Perego, A. and Zerboni, A. 2013. "Inside the African cattle complex: animal burials in the Holocene central Sahara." PLoS ONE 8: 56879.

Dunne, J., Evershed, R.P., Salque, M., Cramp, L., Bruni, S., Ryan, K., Biagetti, S. and di Lernia, S. 2012. "First dairying in green Saharan Africa in the fifth millennium BC." Nature 486: 390-394.

Ehleringer, J.R., Cerling, T.E. and Helliker, B.R. 1997. " $\mathrm{C}_{4}$ photosynthesis, atmospheric $\mathrm{CO}_{2}$, and climate." Oecologia 112: 285-299.

Ehleringer, J.R. and Dawson, T.E. 1992. "Water uptake by plants: perspectives from stable isotope composition." Plant, Cell and Environment 15: 1073-1082.

Ellis, E.C., Kaplan, J.O., Fuller, D.Q. Vavrus, S., Klein Goldewijk, K. and Verburg, P.H. 2013. "Used planet: a global history." Proceedings of the National Academy of Sciences of the United States of America 110: 7978-7985.

Faith, J.T., Tryon, C. A., Peppe, D.J., Beverly, E.J., Blegen, N., Blumenthal, S., Chritz, K. L., Driese, S.G. and Patterson, D. 2015. "Paleoenvironmental context of the MSA record from Karungu, Lake Victoria Basin, Kenya, and its implications for human and faunal dispersals in East Africa." Journal of Human Evolution 83: 28-45.

Farquhar, G., Ehleringer, J.R. and Hubick, K.T. 1989. "Carbon isotope discrimination and photosynthesis." Annual Review of Plant Biology 40: 503-537. 
Faure, G. and Powel, J.L. 1972. Strontium Isotope Geology. Berlin: Springer Verlag.

February, E. and van der Merwe, N.J. 1992. "Stable carbon isotope ratios of wood charcoal during the past 4000 years: anthropogenic and climatic influences." South African Journal of Science 88: 291-292.

Flanagan, L.B., Comstock, J.P. and Ehleringer, J.R. 1991. "Comparison of modelled and observed environmental influences on the stable oxygen and hydrogen isotope composition of leaf water in Phaseolus vulgaris L." Plant Physiology 96: 588-596.

Francey, R.J., Allison, C.E., Etheridge, D.M., Trudinger, C.M., Enting, I.G., Leuenberger, M., Langenfelds, R.L., Michel, E. and Steele, L.P. 1999. "A 1000-year high precision record of delta ${ }^{13} \mathrm{C}$ in atmospheric $\mathrm{CO}_{2} . "$ Tellus 51: 170-193.

Gat, J. 1996. "Oxygen and hydrogen isotopes in the hydrologic cycle." Annual Review of Earth and Planetary Sciences 24: 225-262.

Gebru, T., Eshetu, Z., Huang, Y., Woldemariam, T., Strong, N., Umer, M., DiBlasi, M. and Terwilliger, V.J. 2009. "Holocene palaeovegetation of the Tigray Plateau in northern Ethiopia from charcoal and stable organic carbon isotopic analyses of gully sediments." Palaeogeography, Palaeoclimatology, Palaeoecology 282: 67-80.

Gonfiantini, R., Gratziu, S. and Tongiorgi, E. 1965. "Oxygen isotopic composition of water in leaves." In Isotopes and Radiation in Soil-Plant Nutrition Studies, 405-410. Vienna: International Atomic Energy Agency.

Goodman, A., Jones, J., Reid, J.R., Mack, M., Blakey, M.L., Amarasiriwardena, D., Burton, P. and Coleman, D. 2004. "Isotopic and elemental chemistry of teeth: implications for places of birth, forced migration patterns, nutritional status, and pollution." In The New York African Burial Ground Skeletal Biology Final Report, Vol. 1 edited by M.L. Blakey and M. Rankin-Hill, 216-265. Washington: Howard University.

Hall, M.A. 1986. "The role of cattle in southern African agropastoral societies: more than bones alone can tell." South African Archaeological Society Goodwin Series 5: 83-87.

Handley, L. and Raven, J.A. 1992. "The use of natural abundance of nitrogen isotopes in plant physiology and ecology." Plant, Cell and Environment 15: 965-985.

Harrison, R.G. and Katzenberg, M.A. 2003. "Paleodiet studies using stable carbon isotopes from bone apatite and collagen: examples from southern Ontario and San Nicolas Island, California." Journal of Anthropological Archaeology 22: 227-244.

Heaton, T.H.E. 1987. "The ${ }^{15} \mathrm{~N} /{ }^{14} \mathrm{~N}$ ratios of plants in South Africa and Namibia: relationship to climate and coastal/saline environments." Oecologia 74: 236-246.

Heaton, T.H.E. 1999. "Spatial, species, and temporal variations in the ${ }^{13} \mathrm{C} /{ }^{12} \mathrm{C}$ ratios of $\mathrm{C}_{3}$ plants: implications for palaeodiet studies." Journal of Archaeological Science 26: 637-649.

Huffman, T.N. 1982. "Archaeology and ethnohistory of the African Iron Age." Annual Review of Anthropology 11: 133-150. 
Huffman, T.N. 1996. "Archaeological evidence for climatic change during the last 2000 years in southern Africa." Quaternary International 33: 55-60.

Huffman, T.N. 2000. "Mapungubwe and the origins of the Zimbabwe culture." South African Archaeological Society Goodwin Series 8: 14-29.

Huffman, T.N. 2009. "A cultural proxy for drought: ritual burning in the Iron age of Southern Africa." Journal of Archaeological Science 36: 991-1005.

Johnson, B.J., Miller, G.H., Fogel, M.L. and Beaumont, P.B. 1997. "The determination of late Quaternary paleoenvironments at Equus Cave, South Africa, using stable isotopes and amino acid racemization in ostrich eggshell." Palaeogeography, Palaeoclimatology, Palaeoecology 136: 121-137.

Kennett, D.J., Breitenbach, S.F.M., Aquino, V.V., Asmerom, Y., Awe, J., Baldini, J.U.L., Bartlein, P., Culleton, B.J., Ebert, C., Jazwa, C., Macri, M.J., Marwan, N., Polyak, V., Prufer, K.M., Ridley, H.E., Sodemann, H., Winterhalder, B. and Haug, G.H. 2012. "Development and disintegration of Maya political systems in response to climate change." Science 338: $788-791$.

Kohn, M.J. 1996. "Predicting animal $\delta^{18} \mathrm{O}$ : accounting for diet and physiological adaptation." Geochimica et Cosmochimica Acta 60: 4811-4829.

Kohn, M.J. 2010. "Carbon isotope compositions of terrestrial C3 plants as indicators of (paleo) ecology and (paleo)climate." Proceedings of the National Academy of Sciences of the United States of America 107: 19691-19695.

Krueger, H. and Sullivan, C. 1984. "Models for carbon isotope fractionation between diet and bone." In Stable Isotopes in Nutrition, edited by J. Turnland and P. Johnson, 205-220. Washington: American Chemical Society.

Lambin, E.F., Turner, B.L., Geist, H.J., Agbola, S.B., Angelsen, A., Bruce, J.W., Coomes, O.T., Dirzo, R., Fischer, G., Folke, C., George, P.S., Homewood, K., Imbernon, J., Leemans, R., Li, X., Moran, E., Mortimore, M., Ramakrishnan, P.S., Richards, J.F., Skånes, H., Steffen, W., Stone, G.D., Svedin, U., Veldkamp, T.A., Vogel, C. and Xu, J. 2001. "The causes of land-use and land-cover change: moving beyond the myths." Global Environmental Change 11: 261-269.

Lee-Thorp, J.A. 2008. “On isotopes and old bones.” Archaeometry 50: 925-950.

Lee-Thorp, J.A. and Ecker, M. in press. "Holocene environmental change at Wonderwerk Cave, South Africa: insights from stable light isotopes in ostrich eggshell." African Archaeological Review.

Lee-Thorp, J.A., Holmgren, K., Lauritzen, S. E., Linge, H., Moberg, A., Partridge, T.C., Stevenson, C. and Tyson, P.D. 2001. "Rapid climate shifts in the southern African interior throughout the mid to late Holocene." Geophysical Research Letters 28: 4507-4510. 
Lee-Thorp, J., Sealy, J.C. and Morris, A. 1993. "Isotopic evidence for diets of prehistoric farmers in South Africa." In Prehistoric Human Bone edited by J. Lambert, G. Grupe, 99-120. Berlin: Springer Verlag.

Lee-Thorp, J.A., Sealy, J.C. and van der Merwe, N.J. 1989. "Stable carbon isotope ratio differences between bone collagen and bone apatite, and their relationship to diet." Journal of Archaeological Science 16: 585-599.

Lee-Thorp, J.A., Sponheimer, M., Passey, B.H., de Ruiter, D.J. and Cerling, T.E. 2010. "Stable isotopes in fossil hominin tooth enamel suggest a fundamental dietary shift in the Pliocene." Philosophical Transactions of the Royal Society of London. Series B, Biological Sciences 365: 3389-33496.

Lee-Thorp, J.A., Thackeray, J.F. and van der Merwe, N.J. 2000. "The hunters and the hunted revisited." Journal of Human Evolution 39: 565-576.

Lee-Thorp, J.A. and van der Merwe, N.J. 1987. "Carbon isotope analysis of fossil bone apatite." South African Journal of Science 83: 712-715.

Levin, N.E., Cerling, T.E., Passey, B.H., Harris, J.M. and Ehleringer, J.R. 2006. "A stable isotope aridity index for terrestrial environments." Proceedings of the National Academy of Sciences of the United States of America 103: 11201-11205.

Levin, N.E., Simpson, S.W., Quade, J., Cerling, T.E. and Frost, S.R. 2008. "Herbivore enamel carbon isotopic composition and the environmental context of Ardipithecus at Gona, Ethiopia." Geological Society of America Special Papers 446: 215-234.

Livingstone, D. and Clayton, W. 1980. "An altitudinal cline in tropical African grass floras and its paleoecological significance." Quaternary Research 13: 392-402.

Loftus, E. and Sealy, J.C. 2012. "Interpreting stable carbon isotopes in human tooth enamel: an examination of tissue spacings from South Africa." American Journal of Physical Anthropology 147: 499-507.

Loftus, E., Stewart, B.A., Dewar, G. and Lee-Thorp, J. in press. "Stable isotope evidence of late MIS 3 to middle Holocene palaeoenvironments from Sehonghong Rockshelter, eastern Lesotho." Journal of Quaternary Science.

Marshall, M.H., Lamb, H.F., Davies, S.J., Leng, M.J., Kubsa, Z., Umer, M. and Bryant, C. 2009. "Climatic change in northern Ethiopia during the past 17,000 years: a diatom and stable isotope record from Lake Ashenge.” Palaeogeography, Palaeoclimatology, Palaeoecology 279: 114-127.

McCarroll, D. and Loader, N.J. 2004. "Stable isotopes in tree rings." Quaternary Science Reviews 23: 771-801.

Montgomery, J. 2010. "Passports from the past: investigating human dispersals using strontium isotope analysis of tooth enamel." Annals of Human Biology 37: 325-346. 
Murphy, K.A. 2011. "A meal on the hoof or wealth in the kraal? Stable isotopes at Kgaswe and Taukome in eastern Botswana." International Journal of Osteoarchaeology 21: 591-601.

O’Connell, T.C. and Hedges, R.E.M. 1999. "Investigations into the effect of diet on modern human hair isotopic values." American Journal of Physical Anthropology 108: 409-425.

O'Leary, M. 1981. "Carbon isotope fractionation in plants.” Phytochemistry 20:553-567.

Parker, A.G., Lee-Thorp, J.A. and Mitchell, P.J. 2011. "Late Holocene Neoglacial conditions from the Lesotho highlands, southern Africa: phytolith and stable carbon isotope evidence from the archaeological site of Likoaeng." Proceedings of the Geologists' Association 122: 201-211.

Parkington, J.E. 1972. "Seasonal mobility in the Later Stone Age.” African Studies 31: 223244.

Parkington, J.E. 1976. "Coastal settlement between the mouths of the Berg and Olifants Rivers, Cape Province.” South African Archaeological Bulletin 31: 127-140.

Parkington, J.E. 1991. "Approaches to dietary reconstruction in the western Cape: are you what you have eaten?" Journal of Archaeological Science 18: 331-342.

Passey, B.H., Robinson, T.F., Ayliffe, L.K., Cerling, T.E., Sponheimer, M., Dearing, M.D., Roeder, B.L. and Ehleringer, J.R. 2005. "Carbon isotope fractionation between diet, breath CO2, and bioapatite in different mammals." Journal of Archaeological Science 32: 14591470 .

Price, T.D., Burton, J.H., Cucina, A., Zabala, P., Frei, R., Tykot, R.H. and Tiesler, V. 2012. "Isotopic studies of human skeletal remains from a sixteenth to seventeenth century AD churchyard in Campeche, Mexico." Current Anthropology 53: 396-433.

Price, T.D., Tiesler, V. and Burton, J.H. 2006. "Early African Diaspora in colonial Campeche, Mexico: strontium isotopic evidence." American Journal of Physical Anthropology 130: 485-490.

Roberts, P., Lee-Thorp, J.A., Mitchell, P.J. and Arthur, C. 2013. "Stable carbon isotopic evidence for climate change across the late Pleistocene to early Holocene from Lesotho, southern Africa." Journal of Quaternary Science 28: 360-369.

Rozanski, K., Araguas-Araguas, L. and Gonfantini, R. 1993. "Isotopic patterns in modern precipitation." In Climate Change in Continental Isotopic Records, edited by P. Swart, K. Lohmann, J. McKenzie and S. Savin, 1-36. Washington: American Geophysical Union.

Sadr, K. 2004. "Feasting on Kasteelberg? Early herders on the west coast of South Africa." Before Farming 2004: 1-17.

Sandberg, P.A., Sponheimer, M., Lee-Thorp, J.A. and Van Gerven, D. 2014. "Intra-tooth stable isotope analysis of dentine: a step toward addressing selective mortality in the 
reconstruction of life history in the archaeological record." American Journal of Physical Anthropology 155: 281-293.

Schmidt, S. and Stewart, G.R. 2003. "Delta ${ }^{15} \mathrm{~N}$ values of tropical savanna and monsoon forest species reflect root specialisations and soil nitrogen status." Oecologia 134: 569-577.

Schoeninger, M.J. and DeNiro, M.J. 1984. "Nitrogen and carbon isotopic composition of bone collagen from marine and terrestrial animals." Geochimica et Cosmochimica Acta 48: $625-639$.

Schroeder, H., O'Connell, T.C., Evans, J.A., Shuler, K.A. and Hedges, R.E.M. 2009. "TransAtlantic slavery: isotopic evidence for forced migration to Barbados." American Journal of Physical Anthropology 139: 547-557.

Schwarcz, H.P. and White, C.D. 2004. "The grasshopper or the ant?: cultigen-use strategies in ancient Nubia from C-13 analyses of human hair." Journal of Archaeological Science 31: $753-762$.

Scott, L., Holmgren, K., Talma, S.A., Woodborne, S. and Vogel, J.C. 2003. "Age interpretation of the Wonderkrater spring sediments and vegetation change in the Savanna Biome, Limpopo province, South Africa." South African Journal of Science 99: 484-488.

Sealy, J.C. 1997. "Stable carbon and nitrogen isotope ratios and coastal diets in the LSA of South Africa: a comparison and critical analysis of two data sets." Ancient Biomolecules 1: $131-147$.

Sealy, J.C. 2006. "Diet, mobility, and settlement pattern among Holocene hunter-gatherers in southernmost Africa." Current Anthropology 47: 569-595.

Sealy, J.C. 2010. "Isotopic evidence for the antiquity of cattle-based pastoralism in southernmost Africa." Journal of African Archaeology 8: 65-81.

Sealy, J.C., Armstrong, R. and Schrire, C. 1995. "Beyond lifetime averages: tracing life histories through isotopic analysis of different calcified tissues from archaeological human skeletons.2 Antiquity 69: 290-300.

Sealy, J.C., Morris, A., Armstrong, R., Markell, A. and Schrire, C. 1993. "An historic skeleton from the slave lodge at Vergelegen." South African Archaeological Society Goodwin Series 7: 84-91.

Sealy, J.C. and van der Merwe, N.J. 1985. "Isotope assessment of Holocene human diets in the southwestern Cape, South Africa." Nature 315: 138-140.

Sealy, J.C. and van der Merwe, N.J. 1986. "Isotope assessment and the seasonal-mobility hypothesis in the southwestern Cape of South Africa." Current Anthropology 27: 135-150.

Sealy, J.C. and van der Merwe, N.J. 1988. "Social, spatial and chronological patterning in marine food use as determined by $\delta^{13} \mathrm{C}$ measurements of Holocene human skeletons from the south-western Cape, South Africa." World Archaeology 20: 87-102. 
Sealy, J.C., van der Merwe, N., Lee-Thorp, J.A. and Lanham, J. 1987. "Nitrogen isotopic ecology in southern Africa: implications for environmental and dietary tracing." Geochimica et Cosmochimica Acta 51: 2707-2717.

Sealy, J.C., van der Merwe, N.J., Sillen, A., Kruger, F.J. and Krueger, H.W. 1991. ${ }^{\text {" }}{ }^{87} \mathrm{Sr}{ }^{86} \mathrm{Sr}$ as a dietary indicator in modern and archaeological bone." Journal of Archaeological Science 18: 399-416.

Sillen, A., Hall, G., Richardson, S. and Armstrong, R. 1998. ${ }^{187} \mathrm{Sr} /{ }^{86} \mathrm{Sr}$ ratios in modern and fossil food-webs of the Sterkfontein Valley: implications for early hominid habitat preference." Geochimica et Cosmochimica Acta 62: 2463-2473.

Sillen, A., Sealy, J.C. and van der Merwe, N. 1989. "Chemistry and paleodietary research: no more easy answers." American Antiquity 54: 504-512.

Smith, B.N. and Epstein, S. 1971. "Two categories of ${ }^{13} \mathrm{C} /{ }^{12} \mathrm{C}$ ratios for higher plants." Plant Physiology 47: 380-384.

Smith, J., Lee-Thorp, J.A. and Hall, S. 2007. "Climate change and agropastoralist settlement in the Shashe-Limpopo River Basin, southern Africa: AD 880 to 1700." South African Archaeological Bulletin 62: 115-125.

Smith, J., Lee-Thorp, J.A., Prevec, S., Hall, S. and Spaath, A. 2010. "Pre-colonial herding strategies in the Shashe-Limpopo basin, southern Africa, based on strontium isotope analysis of domestic fauna." Journal of African Archaeology 8: 83-98.

Smith, J., Lee-Thorp, J.A. and Sealy, J.C. 2002. "Stable carbon and oxygen isotopic evidence for late Pleistocene to middle Holocene climatic fluctuations in the interior of southern Africa." Journal of Quaternary Science 17: 683-695,

Sponheimer, M., Alemseged, Z., Cerling, T.E., Grine, F.E., Kimbel, W.H., Leakey, M.G., Lee-Thorp, J.A., Manthi, F.K., Reed, K.E., Wood, B.A. and Wynn, J.G. 2013. "Isotopic evidence of early hominin diets." Proceedings of the National Academy of Sciences of the United States of America 110: 10513-10518.

Sponheimer, M., Codron, D., Passey, B.H., de Ruiter, D.J., Cerling, T.E. and Lee-Thorp, J.A. 2009. "Using carbon isotopes to track dietary change in modern, historical, and ancient primates." American Journal of Physical Anthropology 140: 661-670.

Sponheimer, M. and Lee-Thorp, J.A. 1999. "Alteration of enamel carbonate environments during fossilization.” Journal of Archaeological Science 26: 143-150.

Sponheimer, M., Lee-Thorp, J.A., DeRuiter, D., Smith, J., van der Merwe, N.J., Reed, K., Grant, C.C., Ayliffe, L.K., Robinson, T., Heidelberger, C. and Marcus, W. 2003. "Diets of southern African Bovidae: stable isotope evidence." Journal of Mammalogy 84: 471-479.

Stewart, B.A., Parker, A., Dewar, G.I., Morley, M.W. and Allott, L. in press. "Follow the Senqu: Maloti-Drakensberg paleoenvironments and implications for early human dispersals into mountain systems." In Africa from MIS 6-2: Population Dynamics and Paleoenvironments, edited by Jones, S. and Stewart, B.A. Cham, Switzerland: Springer. 
Stojanowski, C.M. and Knudson, K.J. 2011. "Biogeochemical inferences of mobility of early Holocene fisher-foragers from the southern Sahara Desert." American Journal of Physical Anthropology 146: 49-61.

Stojanowski, C.M. and Knudson, K.J. 2014. "Changing patterns of mobility as a response to climatic deterioration and aridification in the middle Holocene southern Sahara." American Journal of Physical Anthropology 154: 79-93.

Tafuri, M.A., Bentley, R.A., Manzi, G. and di Lernia, S. 2006. "Mobility and kinship in the prehistoric Sahara: Strontium isotope analysis of Holocene human skeletons from the Acacus Mts. (southwestern Libya)." Journal of Anthropological Archaeology 25: 390-402.

Terwilliger, V.J., Eshetu, Z., Huang, Y., Alexandre, M., Umer, M. and Gebru, T. 2011. "Local variation in climate and land use during the time of the major kingdoms of the Tigray Plateau in Ethiopia and Eritrea." Catena 85: 130-143.

Tieszen, L. 1991. "Natural variations in the carbon isotope values of plants: implications for archaeology, ecology, and paleoecology." Journal of Archaeological Science 18: 227-248.

Tieszen, L., Senyimba, M.M., Imbamba, S.K. and Troughton, J.H. 1979. "The distribution of $\mathrm{C} 3$ and $\mathrm{C} 4$ grasses and carbon isotope discrimination along an altitudinal and moisture gradient in Kenya." Oecologia 37: 337-350.

van der Merwe, N.J., Lee-Thorp, J.A., Thackeray, J.F., Hall-Martin, A., Kruger, F.J., Coetzee, H., Bell, R. and Lindeque, M. 1990. "Source-area determination of elephant ivory by isotopic analysis." Nature 346: 744-746.

van der Merwe, N.J. and Medina, E. 1991. "The canopy effect, carbon isotope ratios and foodwebs in Amazonia." Journal of Archaeological Science 18: 249-259.

van der Merwe, N. and Vogel, J.C. 1978. " ${ }^{13} \mathrm{C}$ content of human collagen as a measure of prehistoric diet in woodland North America." Nature 276: 815-816.

Vogel, J.C. 1983. "Isotopic evidence for the past climates and vegetation of southern Africa." Bothalia 14: 391-394.

Vogel, J.C., Fuls, A. and Ellis, R. 1978. "The geographical distribution of Kranz grasses in South Africa." South African Journal of Science 74: 209-219.

Vogel, J.C. and van der Merwe, N.J. 1977. "Isotopic evidence for early maize cultivation in New York State." American Antiquity 42: 238-242.

Von Schirnding, Y., van der Merwe, N.J. and Vogel, J.C. 1982. "Influence of diet and age on carbon isotope ratios in ostrich eggshell." Archaeometry 24: 3-20.

White, C.D. 1993. "Isotopic determination of seasonality in diet and death from Nubian mummy hair.” Journal of Archaeological Science 20: 657-666. 
White, C.D., Longstaffe, F.J. and Law, K.R. 1999. "Seasonal stability and variation in diet as reflected in human mummy tissues from the Kharga Oasis and the Nile Valley." Palaeogeography, Palaeoclimatology, Palaeoecology 147: 209-222.

White, C.D. and Schwarcz, H.P. 1994. "Temporal trends in stable isotopes for Nubian mummy tissues.” American Journal of Physical Anthropology 93: 165-187. 


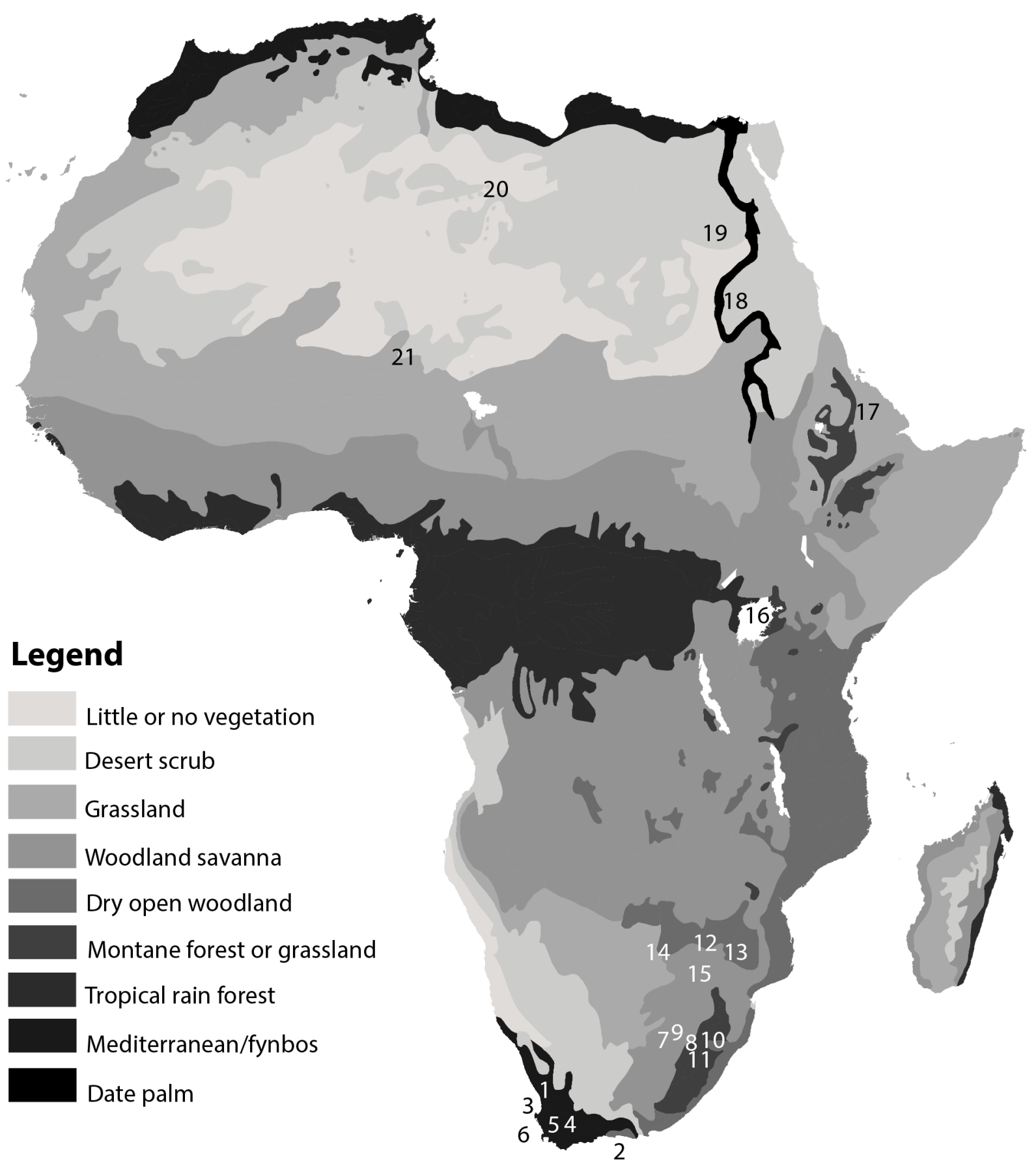

Fig 1: Vegetation map of Africa indicating the approximate location of the main archaeological stable isotope studies discussed in the text.

${ }^{1}$ Various sites (Sealy and van der Merwe 1985, 1986); ${ }^{2}$ Robberg Peninsula and Matjies River Rock shelter (Sealy 2006); ${ }^{3}$ Kasteelberg (Balasse et al. 2002, 2003); ${ }^{4}$ Various sites (Sealy 2010); ${ }^{5}$ Vergelegen (Sealy et al. 1993, 1995); ${ }^{6}$ Cape Foreshore (Cox and Sealy 1999); ${ }^{7}$ Rose Cottage Cave (Smith et al. 2002); ${ }^{8}$ Likoaeng (Parker et al. 2011); ${ }^{9}$ Ntloana Tsoana and Ha Makotoko (Roberts et al. 2013); ${ }^{10}$ Sehonghong (Loftus et al. 2015); ${ }^{11}$ Melikane (Stewart et al. 2015); ${ }^{12}$ Mapungubwe (Smith et al. 2007, 2010); ${ }^{13}$ Phalaborwa; ${ }^{14}$ Toutswe (Murphy, 2011); ${ }^{15}$ various sites (Lee-Thorp et al. 1993); ${ }^{16}$ Karunga (Faith et al. 2015); ${ }^{17}$ Aksum (Marshall et al. 2009 Terwilliger et al. 2011 ); ${ }^{18}$ Wadi Halfa (White 1993); ${ }^{19}$ Kharga Oasis (White et al. 1999); ${ }^{20}$ SW Libya (Tafuri et al. 2006; di Lernia et al., 2013);

${ }^{21}$ Gobero palaeolake basin (Stojanowski and Knudson 2011; 2014). 


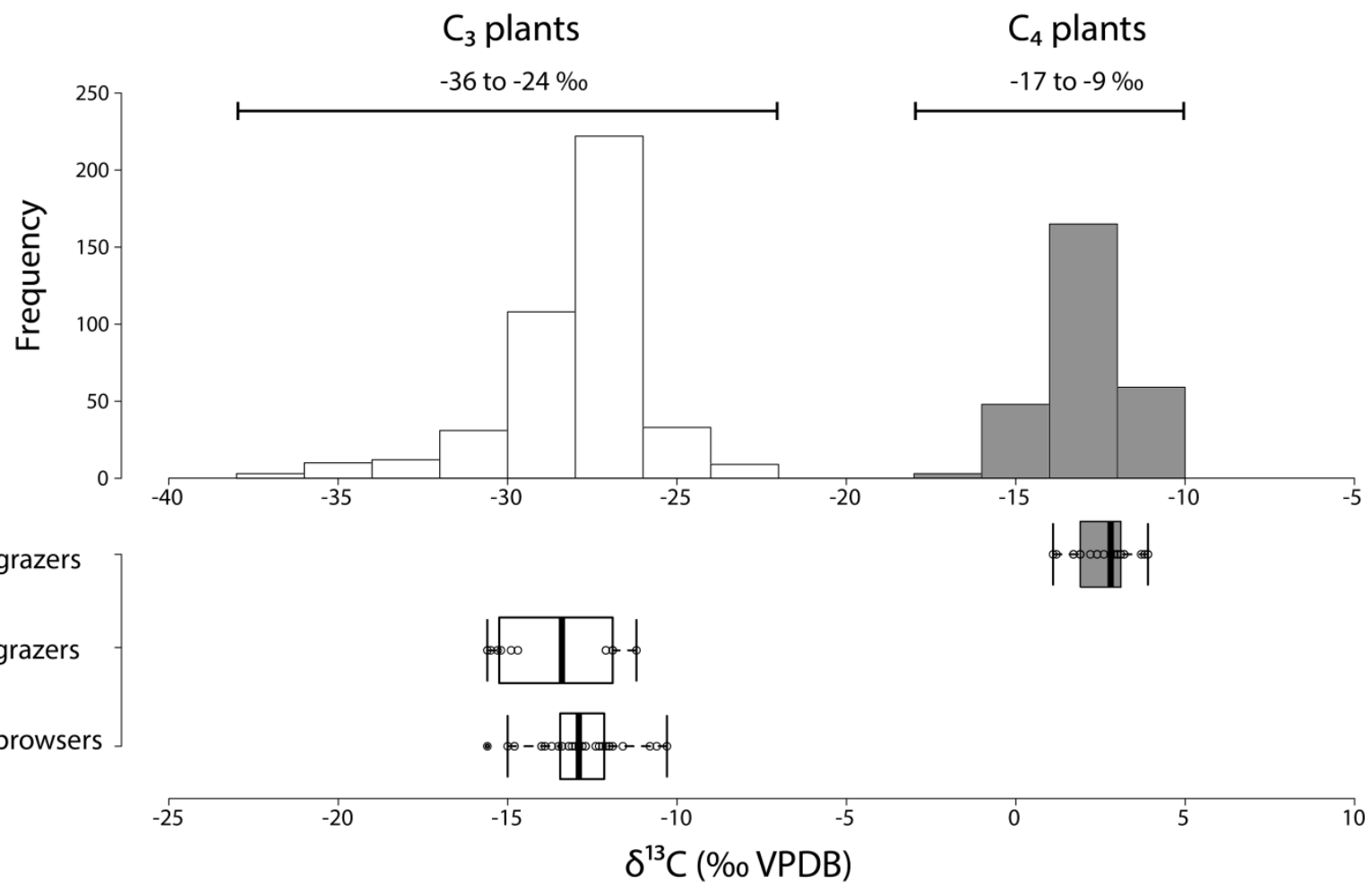

Fig. 2. Above: Histogram of $\delta^{13} \mathrm{C}$ values of East and Central African plant species utilising

$\mathrm{C}_{3}$ (white bars) and $\mathrm{C}_{4}$ (grey bars) photosynthetic mechanisms (data from Cerling et al., 2010). Below: tooth enamel $\delta^{13} \mathrm{C}$ values of grazing and browsing species of large herbivores (data from Cerling and Harris, 1999).

Radiocarbon years (BP)

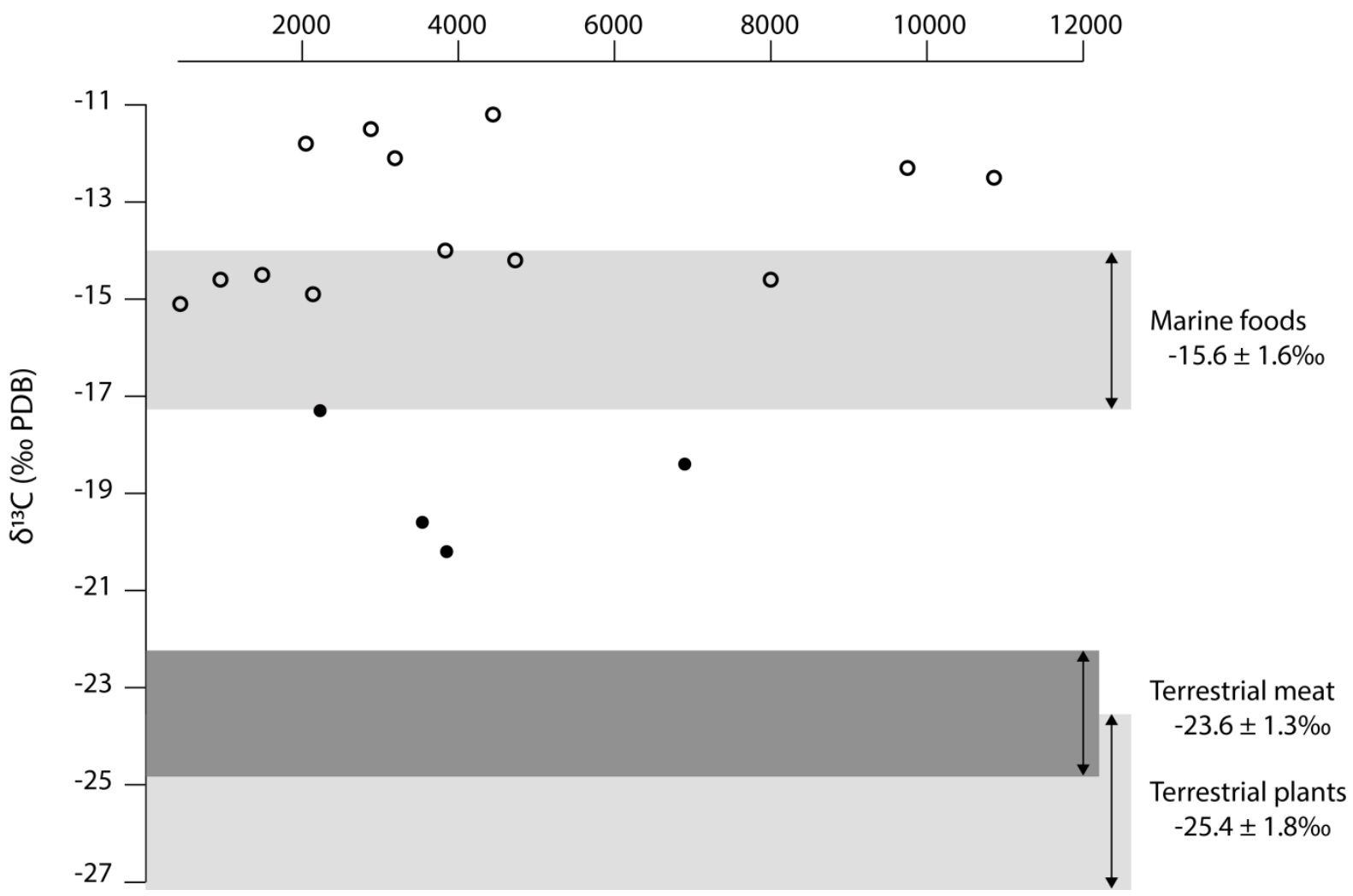


Fig. 3: Bone collagen $\delta^{13} \mathrm{C}$ plotted against radiocarbon years of skeletons buried at the coast (empty circles) and in the interior (filled circles) in the southwestern Cape. The range of values for marine foods, terrestrial meat, and the edible parts of terrestrial plants are indicated. Plot adapted from Lee-Thorp (2008), data from Sealy and van der Merwe (1985, 1986).
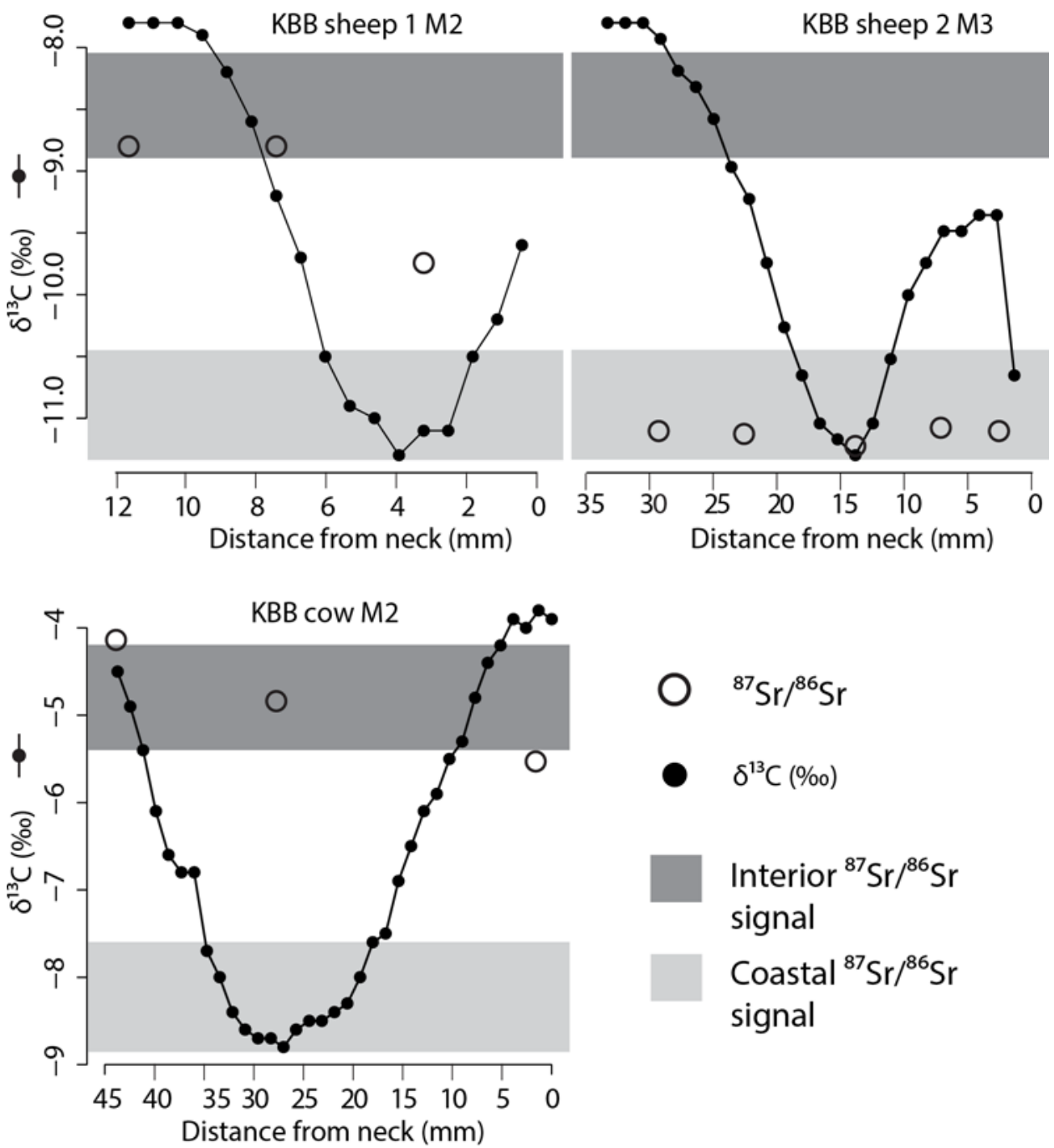

${ }^{87} \mathrm{Sr} /{ }^{86} \mathrm{Sr}$

- $\delta^{13} \mathrm{C}(\%)$

Interior ${ }^{87} \mathrm{Sr} /{ }^{86} \mathrm{Sr}$ signal

Coastal ${ }^{87} \mathrm{Sr} /{ }^{86} \mathrm{Sr}$ signal

Fig. 4: $\delta^{13} \mathrm{C}$ (filled circles) and ${ }^{87} \mathrm{Sr} /{ }^{86} \mathrm{Sr}$ (empty circles) of two sheep teeth and one cow tooth from Kasteelberg, with shaded areas indicating the range of ${ }^{87} \mathrm{Sr} /{ }^{86} \mathrm{Sr}$ values for geological regions. Adapted from Balasse et al. (2002) 


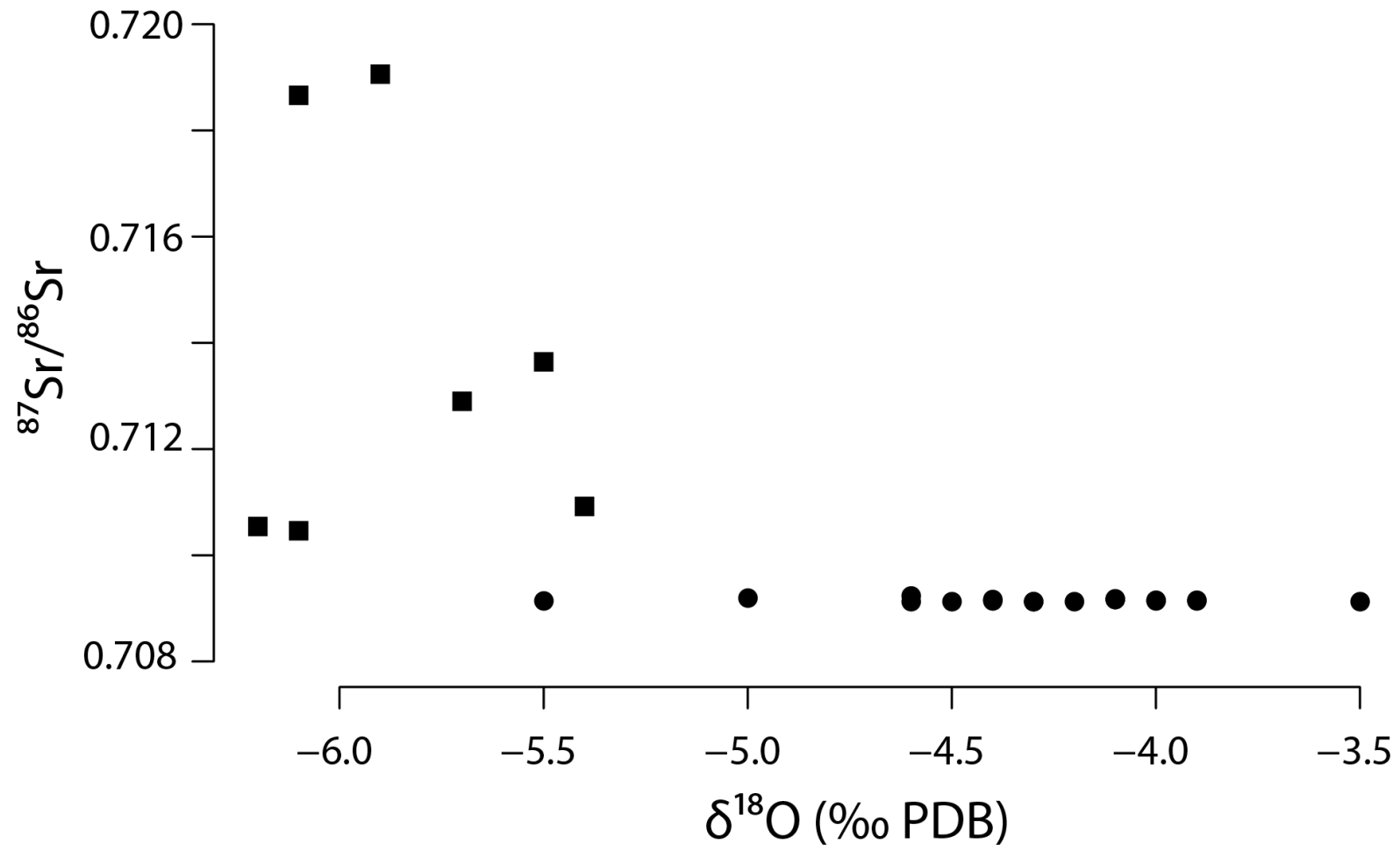

Fig. 5: Enamel carbonate $\delta^{18} \mathrm{O}$ of first molars versus enamel ${ }^{87} \mathrm{Sr} /{ }^{86} \mathrm{Sr}$ for 25 burials of African-born (squares) and Barbados-born (circles) individuals from the Newton plantation cemetery, Barbados. 